\title{
Expression of Nampt in Hippocampal and Cortical Excitatory Neurons Is Critical for Cognitive Function
}

\author{
Liana Roberts Stein, ${ }^{1}$ David F. Wozniak, ${ }^{2,3}$ Joshua T. Dearborn, ${ }^{2}$ Shunsuke Kubota, ${ }^{4}$ Rajendra S. Apte, ${ }^{1,4}$ \\ Yukitoshi Izumi, ${ }^{2,3}$ Charles F. Zorumski, ${ }^{2,5}$ and Shin-ichiro Imai ${ }^{1}$ \\ ${ }^{1}$ Department of Developmental Biology, ${ }^{2}$ Department of Psychiatry, ${ }^{3}$ The Taylor Family Institute for Innovative Psychiatric Research, ${ }^{4}$ Department of \\ Ophthalmology, and 5Department of Anatomy and Neurobiology, Washington University School of Medicine, St. Louis, Missouri 63110
}

\begin{abstract}
Nicotinamide adenine dinucleotide $\left(\mathrm{NAD}^{+}\right)$is an enzyme cofactor or cosubstrate in many essential biological pathways. To date, the primary source of neuronal $\mathrm{NAD}^{+}$has been unclear. $\mathrm{NAD}^{+}$can be synthesized from several different precursors, among which nicotinamide is the substrate predominantly used in mammals. The rate-limiting step in the $\mathrm{NAD}^{+}$biosynthetic pathway from nicotinamide is performed by nicotinamide phosphoribosyltransferase (Nampt). Here, we tested the hypothesis that neurons use intracellular Namptmediated $\mathrm{NAD}^{+}$biosynthesis by generating and evaluating mice lacking Nampt in forebrain excitatory neurons (CaMKII $\boldsymbol{\alpha N a m p t}^{-I-}$

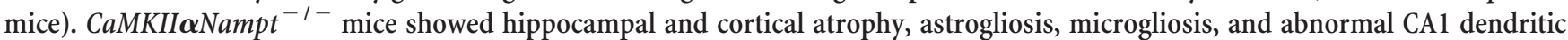
morphology by 2-3 months of age. Importantly, these histological changes occurred with altered intrahippocampal connectivity and abnormal behavior; including hyperactivity, some defects in motor skills, memory impairment, and reduced anxiety, but in the absence of impaired sensory processes or long-term potentiation of the Schaffer collateral pathway. These results clearly demonstrate that forebrain excitatory neurons mainly use intracellular Nampt-mediated $\mathrm{NAD}^{+}$biosynthesis to mediate their survival and function. Studying this particular $\mathrm{NAD}^{+}$biosynthetic pathway in these neurons provides critical insight into their vulnerability to pathophysiological stimuli and the development of therapeutic and preventive interventions for their preservation.
\end{abstract}

Key words: $\mathrm{CA1}$; cognition; hippocampus; $\mathrm{NAD}^{+}$; Nampt

\section{Introduction}

Nicotinamide adenine dinucleotide $\left(\mathrm{NAD}^{+}\right)$is a classic coenzyme used in many critical metabolic pathways such as glycolysis, the tricarboxylic acid cycle, and mitochondrial oxidative phosphorylation (Hirrlinger and Dringen, 2010). $\mathrm{NAD}^{+}$is also required for the synthesis of essential compounds, including most nucleoside triphosphates and some amino acids (Lunt and Vander Heiden, 2011), and for the enzymatic reactions of poly-ADP-ribose polymerases (PARPs), CD38/ CD157 ectoenzymes, and sirtuins (Stein and Imai, 2012). In mammals, $\mathrm{NAD}^{+}$can be synthesized from four precursors: nicotinamide, nicotinic acid, tryptophan, and nicotinamide

Received Nov. 7, 2013; revised March 13, 2014; accepted March 19, 2014.

Author contributions: L.R.S., D.W., R.A., Y.I., C.Z., and S.I. designed research; L.R.S., J.D., S.K., and Y.I. performed research; L.R.S., D.W., S.K., R.A., Y.I., C.Z., and S.I. analyzed data; L.R.S., D.W., Y.I., C.Z., and S.I. wrote the paper.

This work was supported by the National Institutes of Health (National Institute on Aging Grants AG024150 and A G037457 to S.I.; National Institute of Child Health and Human Development P30 Center Grant HD062171 to D.F.W.; National Institute of Mental Health Grant MH077791 to C.F.Z.; and Alafi Neuroimaging Laboratory, Hope Center for Neurological Disorders, and NIH Neuroscience Blueprint Center supported by Core Grant P30 NS05105 to Washington University) and the Ellison Medical Foundation (S.I.). We thank Kazuko A. O'Dell for help with the electrophysiology.

S.I. served as a scientific advisory board member for Sirtris, a GSK company. S.I is also a cofounder of Metro Midwest Biotech. C.F.Z. is affiliated with Sage Therapics. The remaining authors declare no competing financial interests.

Correspondence should be addressed to Shin-ichiro Imai, MD, PhD, Professor, Department of Developmental Biology, Department of Medicine (Joint), Washington University School of Medicine, Campus Box 8103, 660 South Euclid Avenue, St. Louis, M0 63110. E-mail: imaishin@wustl.edu.

DOI:10.1523/JNEUROSCI.4730-13.2014

Copyright $\odot 2014$ the authors $\quad 0270-6474 / 14 / 345800-16 \$ 15.00 / 0$ riboside (Houtkooper et al., 2010; Stein and Imai, 2012). However, the predominantly used pathway is the conversion of nicotinamide to $\mathrm{NAD}^{+}$. The rate-limiting step of this pathway is performed by nicotinamide phosphoribosyltransferase (Nampt; Revollo et al., 2004; Revollo et al., 2007). In mice, protein expression of Nampt is relatively high in brown adipose tissue, liver, and kidney, but nearly undetectable in the pancreas and brain (Kitani et al., 2003; Revollo et al., 2007; Friebe et al., 2011).

Neurons must maintain high rates of oxygen consumption and ATP synthesis for proper function (Barros and Deitmer, 2010). With such high neuronal metabolic activity, glia play an important role in the generation and secretion of energy substrates, such as glucose and monocarboxylic acids, to neurons (Izumi et al., 1997; Pellerin et al., 2007; Barros and Deitmer, 2010; Hirrlinger and Dringen, 2010). However, it has been poorly understood how neurons obtain sufficient $\mathrm{NAD}^{+}$to meet their energetic needs. Although Nampt-mediated NAD ${ }^{+}$ biosynthesis maintains $\mathrm{NAD}^{+}$levels in cultured neurons (Pittelli et al., 2010; Wang et al., 2011b), current work has implied that glia may supply $\mathrm{NAD}^{+}$to neurons because glia possess efficient $\mathrm{NAD}^{+}$biosynthesis machinery, whereas neurons may not (Verderio et al., 2001; Sasaki et al., 2006). Therefore, the fact that Nampt is selectively expressed in neurons of the hippocampus and cortex (Zhang et al., 2010; Wang et al., 2011b), key brain structures in cognition and emotion (Barkus et al., 2010), raises an interesting question: is Nampt-mediated 
$\mathrm{NAD}^{+}$biosynthesis the primary source of $\mathrm{NAD}^{+}$for forebrain neurons?

We hypothesized that forebrain excitatory neurons depend upon intracellular Nampt-mediated $\mathrm{NAD}^{+}$biosynthesis. To test this hypothesis, we generated CaMKII $\alpha$ Nampt $t^{-/-}$mice by crossing Nampt ${ }^{\text {flox/flox }}$ mice with CaMKII $\alpha$ Cre transgenic mice. The CaMKII $\alpha$ Cre driver mediates recombination in forebrain excitatory neurons, primarily in the hippocampal cornu ammonis 1 (CA1) subregion and cortical layers II/III. Recombination begins at postnatal day (P) 14 to $\mathrm{P} 18$, plateaus at $\mathrm{P} 28$, and spreads progressively to the CA3 and dentate gyrus (DG) hippocampal subregions (Tsien et al., 1996; Monteggia et al., 2007; Wang et al., 2011a). We found that CaMKII $\alpha N a m p t^{-/-}$mice exhibit hyperactivity, impaired learning and memory, and reduced levels of anxiety-like behaviors. In light of these remarkable phenotypes, we conclude that forebrain excitatory neurons depend upon intracellular Nampt-mediated $\mathrm{NAD}^{+}$biosynthesis and cannot obtain sufficient $\mathrm{NAD}^{+}$metabolites from other sources for successful cognitive function. Because CA1 sustains the most damage in many prevalent diseases and conditions, CaMKII $\alpha$ Nampt $t^{-1-}$ mice provide critical insight into the importance of Nampt-mediated $\mathrm{NAD}^{+}$biosynthesis for therapeutic/preventive interventions against functional defects in forebrain excitatory neurons.

\section{Materials and Methods}

Animals. Mice were maintained on a regular chow ad libitum diet (PicoLab 5053 Rodent Diet 20; Lab Diets) on a $12 \mathrm{~h}$ light/dark cycle (lights on from 6:00 A.M. to 6:00 P.M.). Parent lines were maintained as homozygous colonies. Nampt $t^{\text {flox/flox }}$ mice (Rongvaux et al., 2008) were crossed to CaMKII $\alpha$ Cre mice (stock \#005359, T29-1; The Jackson Laboratory; Tsien et al., 1996) to generate Nampt flox/+ $^{\text {; Cre dou- }}$ ble heterozygous mice. Double heterozygous mice were bred to Nampt $t^{\text {flox/flox }}$ mice to obtain Nampt $t^{\text {flox/flox }}$; Cre (CaMKII Nampt $^{-1-}$ ) mice. CaMKII $\alpha \mathrm{Nampt}^{-/-}$mice were obtained in the expected Mendelian ratio. In all experiments, "control" mice were age-matched littermates. The CaMKII $\alpha$ Cre driver mice were generated from $8.5 \mathrm{~kb}$ genomic DNA fragment derived from the CaMKII $\alpha$ gene (Tsien et al., 1996). All animal procedures were approved by the Washington University Animal Studies Committee and were in accordance with National Institutes of Health guidelines.

Immunohistochemistry. Mice were anesthetized by intraperitoneal injection of ketamine and xylazine and perfused transcardially through the left ventricle with cold $0.1 \mathrm{~m}$ phosphate buffer, $\mathrm{pH}$ 7.4, followed by a phosphate-buffered solution of $4 \%$ paraformaldehyde (PFA). Brains were postfixed with $4 \%$ PFA overnight, equilibrated in 15\% sucrose overnight, equilibrated in $30 \%$ sucrose overnight, frozen, and stored at $-80^{\circ} \mathrm{C}$ until sectioning. Then, $30 \mu \mathrm{m}$ coronal sections in a 1 in 8 series were made by cryostat and stored at $-30^{\circ} \mathrm{C}$ in cryoprotectant until use. Every eighth section was processed free floating. Tissue sections were incubated in $50 \%$ formamide in $2 \times$ saline/sodium citrate at $65^{\circ} \mathrm{C}$ for $2 \mathrm{~h}$ for Nampt immunostaining or $10 \mathrm{~mm}$ citrate buffer at $65^{\circ} \mathrm{C}$ for $1 \mathrm{~h}$ for all other antibodies before proceeding with the staining protocol. To remove endogenous peroxidase activity, all sections were incubated with $3 \% \mathrm{H}_{2} \mathrm{O}_{2}$ for $10 \mathrm{~min}$. Tissue sections were incubated in blocking/permeabilization solution containing $10 \%$ normal goat serum, $1 \%$ BSA, and $0.3 \%$ Triton-X in PBS for $45-60$ min before $24 \mathrm{~h}$ of incubation with primary antibodies in 5\% normal goat serum and $0.1 \%$ Triton-X in PBS at $4^{\circ} \mathrm{C}$ at the following dilutions: activated caspase 3 (1:500, \#9661, rabbit; Cell Signaling Technology), Ibal (1:500, \#019-19741, rabbit; Wako), Gfap (1:1000, MAB360, mouse; Millipore), Map2 (1:500, M9942, mouse; Sigma), Nampt (1:1000, ALX-804-717-C100, mouse; Alexis Biochemicals), NeuN (1:500, MAB377, mouse; Millipore), PSD95 (1:500, \#2507, rabbit; Cell Signaling Technology), Synaptophysin (1:1000, S5768, mouse; Sigma), VGlut1 (1:1000, 135 304, guinea pig; Synaptic Systems). All antibody specificity was determined by lack of staining after omission of primary or secondary antibodies. Alexa Fluor 627 (1:200), Alexa Fluor 488 (1:200), or Cy3 (1:400) conjugated-secondary antibodies (Jackson ImmunoResearch) diluted in $2 \%$ normal goat serum, $1 \%$ BSA, and $0.1 \%$ Triton-X in PBS were added for $2 \mathrm{~h}$ at room temperature. Detection of Nampt, Synaptophysin, and Map2 was performed using the TSA-Plus cyanine 5 kit (PerkinElmer). Nuclei were stained with 4,6-diamidino-2phenylindole (Sigma) for $10 \mathrm{~min}$ at room temperature. Highmagnification $(20 \times, 0.8$ DIC II or $40 \times$ oil 1.3 DIC II) microscopic imaging was performed using a Zeiss Axioimage.Z1 or an Olympus NanoZoomer 2.0-HT. Images were taken in $z$-stacks of $1 \mu \mathrm{m}$ steps through the range of tissue section immunoreactivity. Quantification was performed blinded to genotype on 2-3 tissue sections per animal. Verification of colocalization was achieved by performing $3 \mathrm{D}$ rendering on stacks of $Z$-images with ImageJ.

Golgi-Cox staining and analysis. Mice were decapitated and the brains were quickly removed from the skull, washed in MilliQ water, and processed immediately for impregnation using the Rapid GolgiStain kit according to manufacturer's instructions (FD NeuroTechnologies). Brains were sectioned using a cryostat at $-22^{\circ} \mathrm{C}$ at a thickness of $100 \mu \mathrm{m}$. Golgi-impregnated neurons were filled completely such that their soma and dendrites were clearly visible. Neurons located in CAl's stratum pyramidale were traced with ImageJ's NeuronJ plugin and Sholl analysis was performed with ImageJ's Sholl analysis plugin, with spheres centered on the soma, beginning at a radius of $20 \mu \mathrm{m}$ and increasing in size by 10 $\mu \mathrm{m}$ increments.

Western blotting. Protein extracts $(15-50 \mu \mathrm{g})$ were prepared from acutely isolated mouse hippocampi flash frozen in liquid nitrogen and stored at $-80^{\circ} \mathrm{C}$ until use, as described previously (Yoshino et al., 2011). Membranes were incubated with primary antibodies in TBST overnight at $4^{\circ} \mathrm{C}$. Primary antibodies used: activated caspase 3 (1:1000, \#9661, rabbit; Cell Signaling Technology), Gfap (1:3000, MAB360, mouse; Millipore), LC3 (1:2000; NB600-1384, rabbit; Novus), Map2 (1:1000, M9942, mouse; Sigma), Nampt (1:3000; ALX-804-717-C100, mouse; Alexis Biochemicals), Spectrin (1:1000, MAB1622, mouse; Millipore), Synaptophysin (1:1000, S5768, mouse; Sigma), and $\beta$-tubulin (1:500, sc-9104, rabbit; Santa Cruz Biotechnology).

Quantitative real-time RT-PCR. Total RNA was isolated from mouse hippocampi flash frozen in liquid nitrogen and stored at $-80^{\circ} \mathrm{C}$ before extraction using the RNeasy kit (QIAGEN). RNA was reverse transcribed into cDNA with the High Capacity cDNA Reverse Transcription kit (Applied Biosystems). Quantitative real-time RT-PCR was conducted with the TaqMan Fast Universal PCR Master mix and appropriate TaqMan primers for each gene in the GeneAmp 7500 fast sequence detection system (Applied Biosystems). Relative expression levels were calculated for each gene by normalizing to GAPDH levels and then to a control.

Experimental design of behavioral studies. Behavioral tests were conducted on two separate cohorts of CaMKII $\alpha \mathrm{Nampt}^{-{ }^{-1-}}$ and littermate control mice. The first cohort of CaMKII $\alpha$ Nampt $t^{-1-}$ mice $(n=16$; 7 male, 8 female) and littermate control mice ( $n=15 ; 7$ male, 8 female) was evaluated on the $1 \mathrm{~h}$ locomotor activity test, battery of sensorimotor measures, Morris water maze (MWM) navigation task, and conditioned fear, in that order. The second, naive cohort of CaMKII $\alpha$ Nampt $t^{-1-}$ mice ( $n=16 ; 7$ male, 9 female) and littermate control mice $(n=15 ; 7$ male, 8 female) was tested on the elevated plus maze (EPM). Behavioral tests were conducted by observers unaware of the genotypes of individual mice.

One hour locomotor activity and sensorimotor battery. Locomotor activity was evaluated using transparent $(47.6 \times 25.4 \times 20.6 \mathrm{~cm}$ high $)$ polystyrene enclosures and computerized photobeam instrumentation as described previously (Wozniak et al., 2004; Dougherty et al., 2013). General activity variables (total ambulations, vertical rearings, along with indices of emotionality including time spent, distance traveled and entries made in a $33 \times 11 \mathrm{~cm}$ central zone, and distance traveled in a $5.5 \mathrm{~cm}$ contiguous peripheral zone were analyzed. The following day, mice were evaluated on a battery of sensorimotor tests designed to assess balance (ledge and platform), strength (inverted screen), coordination (pole and inclined screens), and initiation of movement (walking initiation), as described previously (Wozniak et al., 2004; Grady et al., 2006). For the walking initiation test, a mouse was placed on a surface in the center of a 
$21 \times 21 \mathrm{~cm}$ square marked with tape and the time the mouse took to leave the square was recorded. During the balance tests, the time that a mouse remained on a Plexiglas ledge $(0.75 \mathrm{~cm}$ wide $)$ or a small circular wooden platform $(3.0 \mathrm{~cm}$ in diameter) elevated 30 or $47 \mathrm{~cm}$, respectively, was recorded. The pole test involved placing a mouse "head up" with its forepaws on top of a finely textured rod (diameter $8 \mathrm{~mm}$; height $55 \mathrm{~cm}$ ) and timing how long it took the mouse to turn and climb down the pole. If the mouse fell off the pole during a trial, it received a maximum score of $120 \mathrm{~s}$. The screen tests were conducted by placing a mouse headoriented down in the middle a wire mesh grid measuring 16 squares per $10 \mathrm{~cm}$, elevated $47 \mathrm{~cm}$ and angled at $60^{\circ}$ or $90^{\circ}$. The time the mouse required to turn $180^{\circ}$ and climb to the top of the apparatus was recorded. For the inverted screen, a mouse was placed on the screen as described previously in this section. Once the mouse appeared to have a secure grip, the screen was inverted $180^{\circ}$ and the time the mouse remained on the screen was recorded. Each test had a maximum time of $60 \mathrm{~s}$, except for the pole test, which had a maximum time of $120 \mathrm{~s}$. The averaged time of two trials for each test was used for the analyses.

MWM navigation. Spatial learning and memory were evaluated by the MWM using a computerized tracking system (ANY-maze; Stoelting) as described previously (Wozniak et al., 2004; Dougherty et al., 2013) the day after the completion of the sensorimotor battery. Cued (visible platform, variable location) and place (submerged, hidden platform, constant location) trials were conducted and escape path length, latency, and swimming speeds were computed. The cued condition involved conducting four trials per day (60 s maximum per trial) for two consecutive days with the platform being moved to a different location for each trial using a $30 \mathrm{~min}$ intertrial interval (ITI) and with very few distal spatial cues being present to limit spatial learning. Performance was analyzed across four blocks of trials (two trials/block). Three days later, place trials were initiated to assess spatial learning, in which mice were required to learn the single location of a submerged platform in the presence of several salient distal spatial cues. During place trials, the mice received 2 blocks of 2 consecutive trials ( $60 \mathrm{~s}$ maximum for a trial; $30 \mathrm{~s}$ ITI spent on platform) with each block being separated by $\sim 2 \mathrm{~h}$ and each mouse being released from a different quadrant for each trial. The place trials data were analyzed over five blocks of trials (four trials/block), in which each block represented the performance level for each of five consecutive days. A probe trial ( $60 \mathrm{~s}$ maximum) was administered $\sim 1 \mathrm{~h}$ after the last place trial on the fifth day of training with the platform being removed and the mouse being released from the quadrant opposite to where the platform had been located. Time spent in the various pool quadrants, including the target quadrant where the platform had been placed, and crossings over the exact platform location served as the dependent variables.

Conditioned fear. Conditioned fear was evaluated as described previously (Wozniak et al., 2007; Sato et al., 2012) 54 d after examining spatial learning and memory in the MWM. Briefly, mice were trained and tested in two Plexiglas conditioning chambers $(26 \mathrm{~cm} \times 18 \mathrm{~cm}$, and $18 \mathrm{~cm}$ high; Med-Associates), with each chamber containing distinct and different visual, odor, and tactile cues. Each mouse was placed into the conditioning chamber for a $5 \mathrm{~min}$ trial and freezing behavior was quantified during a $2 \mathrm{~min}$ baseline period. Beginning at $3 \mathrm{~min}$ and at $60 \mathrm{~s}$ intervals thereafter, the mice were exposed to $3 \mathrm{~T} / \mathrm{S}$ pairings, with each pairing including a 20 s presentation of an $80 \mathrm{~dB}$ tone (conditioned stimulus; CS) consisting of broadband white noise followed by a $1.0 \mathrm{~mA}$ continuous foot shock (unconditioned stimulus; US) presented during the last second of the tone. Broadband white noise was used instead of a frequency-specific tone in an effort to avoid possible auditory deficits that might occur with age. The mice were placed back into the conditioning chamber the following day and freezing behavior was quantified over an $8 \mathrm{~min}$ period to evaluate contextual fear conditioning. Twenty-four hours later, the mice were placed into a different chamber containing different cues. Freezing behavior was quantified during a 2 min "altered context" baseline and over the subsequent $8 \mathrm{~min}$, during which time the auditory cue (tone; CS) was presented. Freezing was quantified using FreezeFrame image analysis software (Actimetrics), which allowed for simultaneous visualization of behavior while adjusting a "freezing threshold," which categorized behavior as freezing or not freezing during $0.75 \mathrm{~s}$ intervals. Freezing was defined as no movement except for that associated with normal respiration and the data are presented as percentage of time spent freezing. Shock sensitivity was evaluated after completion of the conditioned fear testing according to our previously described procedures (Khuchua et al., 2003).

EPM. Anxiety-like behaviors were assessed using the EPM according to our previously described procedures (Schaefer et al., 2000; Dougherty et al., 2013). Our apparatus consisted of two opposing open arms and two opposing enclosed arms $(36 \times 6.1 \times 15 \mathrm{~cm})$ that extended from a central platform $(5.5 \times 5.5 \mathrm{~cm})$ constructed of black Plexiglas. The maze was equipped with pairs of photocells configured in a 16 ( $x$-axis $) \times 16(y$ axis) matrix, the output of which was recorded by a computer and interface assembly (Kinder Scientific). A system software program (MotorMonitor; Kinder Scientific) enabled the beam-break data to be recorded and analyzed to quantify time spent, distance traveled, and entries made into the open and closed arms and center area. To adjust for differences in general activity, the percentage of distance traveled, time spent, and entries made into the open arms out of the totals (open arms + closed arms) for each variable were also computed. Test sessions were conducted in a dimly lit room where light was provided by two 13-watt blacklight bulbs (EcoBulbs; Feit) and each session began by placing a mouse in the center of the maze and allowing it to freely explore the apparatus. Each test session lasted $5 \mathrm{~min}$ and the mice were tested over 3 consecutive days.

LTP. LTP was evaluated using previously described methods (Bukalo and Dityatev, 2006; Tokuda et al., 2010). Briefly, hippocampal slices were prepared from 60 -d-old mice. Mice were anesthetized with isoflurane and decapitated. Hippocampi were rapidly dissected and placed in artificial CSF (ACSF) containing the following (in $\mathrm{mM}$ ): $124 \mathrm{NaCl}, 5 \mathrm{KCl}, 2$ $\mathrm{MgSO}_{4}, 2 \mathrm{CaCl}_{2}, 1.25 \mathrm{NaH}_{2} \mathrm{PO}_{4}, 22 \mathrm{NaHCO}_{3}, 10$ glucose, gassed with $95 \% \mathrm{O}_{2}-5 \% \mathrm{CO}_{2}$ at $4-6^{\circ} \mathrm{C}$, and sectioned transversely into $400-450 \mu \mathrm{m}$ slices using a rotary slicer. Acutely prepared slices were placed in an incubation chamber containing gassed ACSF for at least $1 \mathrm{~h}$ at $30^{\circ} \mathrm{C}$. Slices were then transferred individually to a submersion-recording chamber. Experiments were performed at $30^{\circ} \mathrm{C}$ with continuous perfusion of ACSF at $2 \mathrm{ml} / \mathrm{min}$. Extracellular recordings were obtained from the CA1 apical dendritic region (stratum radiatum) for analysis of field EPSPs (fEPSPs) and from the pyramidal cell layer (stratum pyramidale) for analysis of fiber volleys and population spikes using $2 \mathrm{M} \mathrm{NaCl}$ glass electrodes (5-10 M $\Omega$ ). Responses were elicited with $0.1 \mathrm{~ms}$ constant current pulses through a bipolar electrode in the Schaffer collateral pathway. fEPSPs were measured by the maximal slope of their rising phase and fiber volleys and population spikes were measured as maximal peakto-trough amplitudes. A baseline (control) input-output (IO) curve was obtained to determine stimulus intensities for subsequent analyses. IO curves were generated using stimuli of six different intensities to allow determination of half-maximal responses. The smallest stimulus was set to evoke a response less than half maximal and the largest stimulus was designed to evoke a fully saturated response. During an experiment, evoked fEPSPs were monitored by applying single stimuli to the Schaffer collateral pathway every $60 \mathrm{~s}$ at an intensity sufficient to elicit half maximal responses. After establishing a stable baseline, LTP was induced by applying a single $100 \mathrm{~Hz} \times 1 \mathrm{~s}$ high-frequency stimulus (HFS) using a stimulus of the same intensity. IO curves were repeated $60 \mathrm{~min}$ after delivery of low-frequency stimulation (LFS; $1 \mathrm{~Hz} \times 900$ pulses) and then $60 \mathrm{~min}$ after delivery of $\mathrm{HFS}(100 \mathrm{~Hz} \times 100$ pulses $\times 1 \mathrm{~s})$ to determine the magnitude of LTP based on changes in half maximal responses.

For investigation of paired-pulse plasticity, dual stimuli of identical intensity were delivered at an interval of $21 \mathrm{~ms}$. The stimulus intensity was initially set below threshold for evoking responses and increased in a stepwise fashion every $10 \mathrm{~s}$ until six pairs of stimuli were administered. Methods for analyzing paired-pulse changes in somatic excitability based on IO curves are detailed in the Figure 5C legend.

Statistical analyses. All numerical data are presented as mean \pm SEM. Statistical significance between control and experimental samples was determined by unpaired Student's $t$ tests with $p<0.05$ representing a statistically significant difference. For the behavioral data, ANOVA models were used. Repeated-measures ANOVA (rmANOVA) models containing two between-subjects variables (genotype and sex) and one within-subject (repeated-measures) variable (e.g., blocks of trials) were 

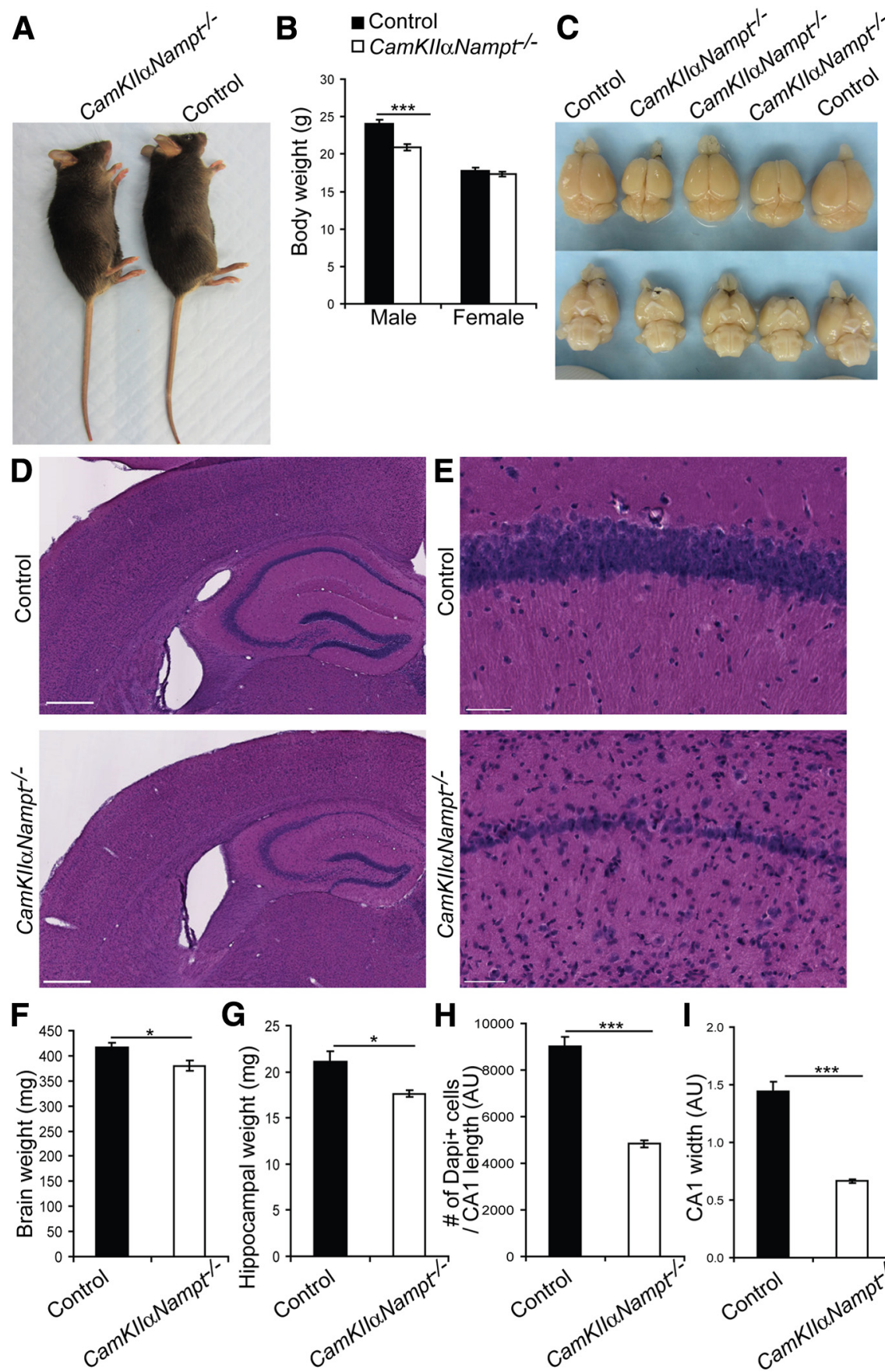

H

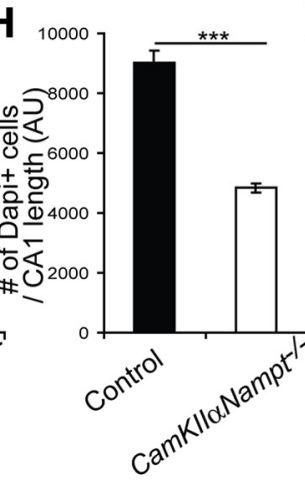

Figure 1. CaMKIl $\alpha \mathrm{Nampt}^{-1-}$ mice are overtly normal but show altered CA1 morphology at 2-3 months of age. $\boldsymbol{A}$, Representative images of CaMKIl $\alpha$ Nampt ${ }^{-1-}$ and control mice. B, Body weights of CaMKIl $\alpha$ Nampt ${ }^{-1-}$ mice $(n=22-26)$ and control mice $(n=20-26)$. C, Representative images of the brains of CaMKIl $\alpha N_{\text {ampt }}{ }^{-1}$ - and control mice. D, H\&E staining of coronal brain sections. Scale bars, $500 \mu \mathrm{m}$. E, Magnification of the CA1 hippocampal subregion from $\boldsymbol{D}$. Scale bars, $50 \mu \mathrm{m}$. $\boldsymbol{F}$, Brain weights of CaMKIl $\alpha \mathrm{Nampt}^{-1-}$ and control mice $(n=5)$. G, Hippocampal weights of CaMKIl $\alpha$ Nampt ${ }^{-1-}$ and control mice ( $n=5)$. $\boldsymbol{H}, \boldsymbol{I}$, Quantification of immunohistochemistry in the CA1 stratum pyramidale $(n=5)$. $\boldsymbol{H}$, The number of DAPI ${ }^{+}$cells present per length of the CA1 stratum pyramidale. I, Width of the CA1 stratum pyramidale, calculated as CA1 area per CA1 length. Data are presented as mean \pm SEM. ${ }^{*} p<0.05 ;{ }^{* *} p<0.01$; ${ }^{* *} p<0.001$.

typically used to analyze the MWM, conditioned fear, and EPM data. The Huynh-Feldt adjustment of $\alpha$ levels was used for all within-subject effects containing more than two levels to protect against violations of sphericity/compound symmetry assumptions underlying rmANOVA models. Typically, one-way ANOVA models were used to analyze differences between groups for measures in the $1 \mathrm{~h}$ locomotor activity and the sensorimotor battery tests. Pairwise comparisons were conducted after relevant, significant overall ANOVA effects and were subjected to

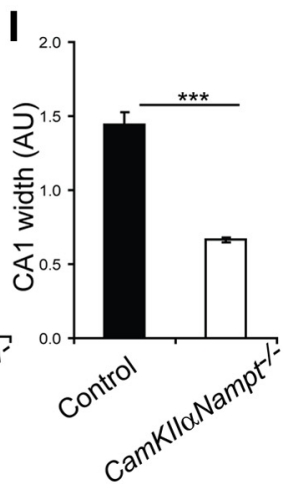

Bonferroni correction when appropriate, although planned comparisons were also conducted.

\section{Results}

\section{CaMKII $\alpha$ Nampt $^{-/-}$mice are overtly} normal but show altered CA1 morphology at 2-3 months of age

At 2-3 months of age, CaMKII $\alpha$ Nampt $^{-1-}$ mice looked overtly normal relative to littermate control mice (Fig. 1A). The body weights of female CaMKII $\alpha \mathrm{Nampt}^{-/-}$ mice were indistinguishable from control mice (Student's $t$ test, $p=0.38, n=22-26$ ), whereas the body weights of male CaMKII $\alpha$ Nampt $t^{-1-}$ mice were slightly, but significantly, lower than control mice (Fig. 1B; Student's $t$ test, $p=0.0001, n=$ 20-26). Because the CaMKII $\alpha C r e$ driver mediates recombination in excitatory neurons of the forebrain, we examined the morphology of CaMKII $\alpha \mathrm{Nampt}^{-1-}$ and control brains by gross inspection and $\mathrm{H} \& \mathrm{E}$ staining (Fig. 1C-E). CaMKII $\alpha N_{N a m p t}{ }^{-1-}$ brains looked slightly smaller than control brains at 2-3 months of age (Fig. 1C). Consistent with this observation, we noticed a visible decrease in the thickness of the CA1 stratum pyramidale and an increase in total cells present in the stratum radiatum and stratum oriens. Quantitatively, the total brain weight of CaMKII $\alpha \mathrm{Nampt}^{-/-}$mice was $9 \%$ smaller than that of control mice (Fig. 1F; Student's $t$ test, $p=0.03, n=5$ ). Similarly, the total weight of each hippocampi in CaMKII $\alpha$ Nampt $t^{-/-}$mice was $16 \%$ smaller than that of control mice (Fig. $1 G$; Student's $t$ test, $p=0.01, n=5)$. Using DAPI staining to quantify the cell loss, we found that CaMKII $\alpha$ Nampt $t^{-1-}$ mice had $44 \%$ fewer DAPI ${ }^{+}$cells in (Student's $t$ test, $p=0.00001, n=5)$ and a $54 \%$ decrease in the width of CA1's stratum pyramidale (Fig. $1 H, I$; Student's $t$ test, $p=0.00001, n=5$ ).

To validate the recombination pattern produced by the CaMKII $\alpha$ Cre driver, we examined Nampt protein expression by immunohistochemistry in 2- to 3-monthold CaMKII $\alpha$ Nampt $t^{-/-}$and control mice. In both genotypes, Nampt was expressed in neurons, but not astrocytes, of the hippocampus, as shown previously (Zhang et al., 2010; Wang et al., 2011b; Fig. $2 A-C)$. However, CaMKII $\alpha N_{a m p t}{ }^{-1-}$ mice exhibited a striking loss of Nampt immunoreactivity in neurons of the CA1 subregion of the hippocampus (Fig. $2 \mathrm{~A}$ ) and, to a lesser extent, in neurons of the DG and CA3 subregions (Fig. $2 B, C)$. Quantification of these differences in CA1 revealed that CaMKII $\alpha$ Nampt $t^{-1-}$ mice had 38\% fewer cells expressing Nampt (Fig. 2D; Student's $t$ test, $p=0.0007, n=5$ ). Immunoblotting whole hippocampal extracts showed a significant $30 \%$ decrease in Nampt protein levels in CaMKII $\alpha \mathrm{Nampt}^{-/-}$relative 
to control mice (Fig. 2E; $0.54 \pm 0.04$ in CaMKII $\alpha \mathrm{Nampt}^{-/-}$mice vs $0.77 \pm 0.04$ in control mice at 6-7 months of age; Student's $t$ test, $p=0.006$, Nampt intensity normalized by $\beta$-tubulin, $n=9$ ). This $30 \%$ reduction in Nampt protein expression is consistent with the CA1-specific nature of the deletion. To further confirm the reduction in Nampt, we measured $\mathrm{NAD}^{+}$levels in hippocampal extracts of 2- to 3-month-old CaMKII $\alpha$ Nampt ${ }^{-/-}$ and control mice (Fig. 2F). Hippocampal $\mathrm{NAD}^{+}$levels in CaMKII $\alpha$ Nampt ${ }^{-1-}$ mice were reduced $26 \%$ relative to control mice (Student's $t$ test, $p=0.007, n=12-$ 14), whereas ATP levels between the two genotypes were indistinguishable (Fig. $2 G$; Student's $t$ test, $p=0.34, n=12$ ). CaMKII $\alpha$ Nampt $t^{-1-}$ mice also exhibited identical mortality rates relative to control mice through 14 months of age (the latest age checked, data not shown).

\section{CaMKII $\alpha$ Nampt $^{-1-}$ mice exhibit} astrogliosis and microgliosis in the forebrain

As in the hippocampus, Nampt immunoreactivity appeared to be reduced in the cortex of CaMKII $\alpha \mathrm{Nampt}^{-1-}$ mice relative to control mice (Fig. $3 A$ ). In control mice, cortical layer I was easily distinguishable by its low cell density (Fig. $3 A, B$ ). In contrast, the cortical layers of CaMKII $\alpha \mathrm{Nampt}^{-/-}$mice were indistinguishable by cell density. Although loss of $\mathrm{NeuN}^{+}$neurons was mainly prevalent in CA1, all three hippocampal subregions and the cortex also demonstrated a dramatic increase in Gfap ${ }^{+}$immunoreactivity (Fig. 3A), suggesting astrogliosis. Because of this massive astrogliosis, we investigated whether the populations of other cell types were affected. Immunohistochemistry for Ibal also revealed extensive microglial activation in all hippocampal subregions and the cortex, indicative of an inflammatory response (Fig. 3B). Quantitative PCR analysis revealed a 6-fold increase in Gfap (Student's $t$ test, $p=$ $0.0000004, n=11-14$ ) and a 2.3-fold increase in Ibal (Student's $t$ test, $p=0.002, n=11-14$ ) mRNA expression in the hippocampi of CaMKII $\alpha \mathrm{Nampt}^{-/-}$mice relative to control mice (Fig. 3C).

Due to the substantial neuronal loss in the CA1 subregion of 2- to 3-month-old CaMKII $\alpha \mathrm{Nampt}^{-1-}$ mice (Figs. 1E, 2A), we investigated whether the Nampt-deficient neurons were dying. Immunohistochemistry for TUNEL (Fig. 3B) or activated caspase 3 (Fig. 3D), markers of cell death, revealed very few positive cells in either genotype, indicating that neither apoptosis nor necrosis was occurring at substantial levels at this

A
B Dentate gyrus Dapi Nampt NeuN
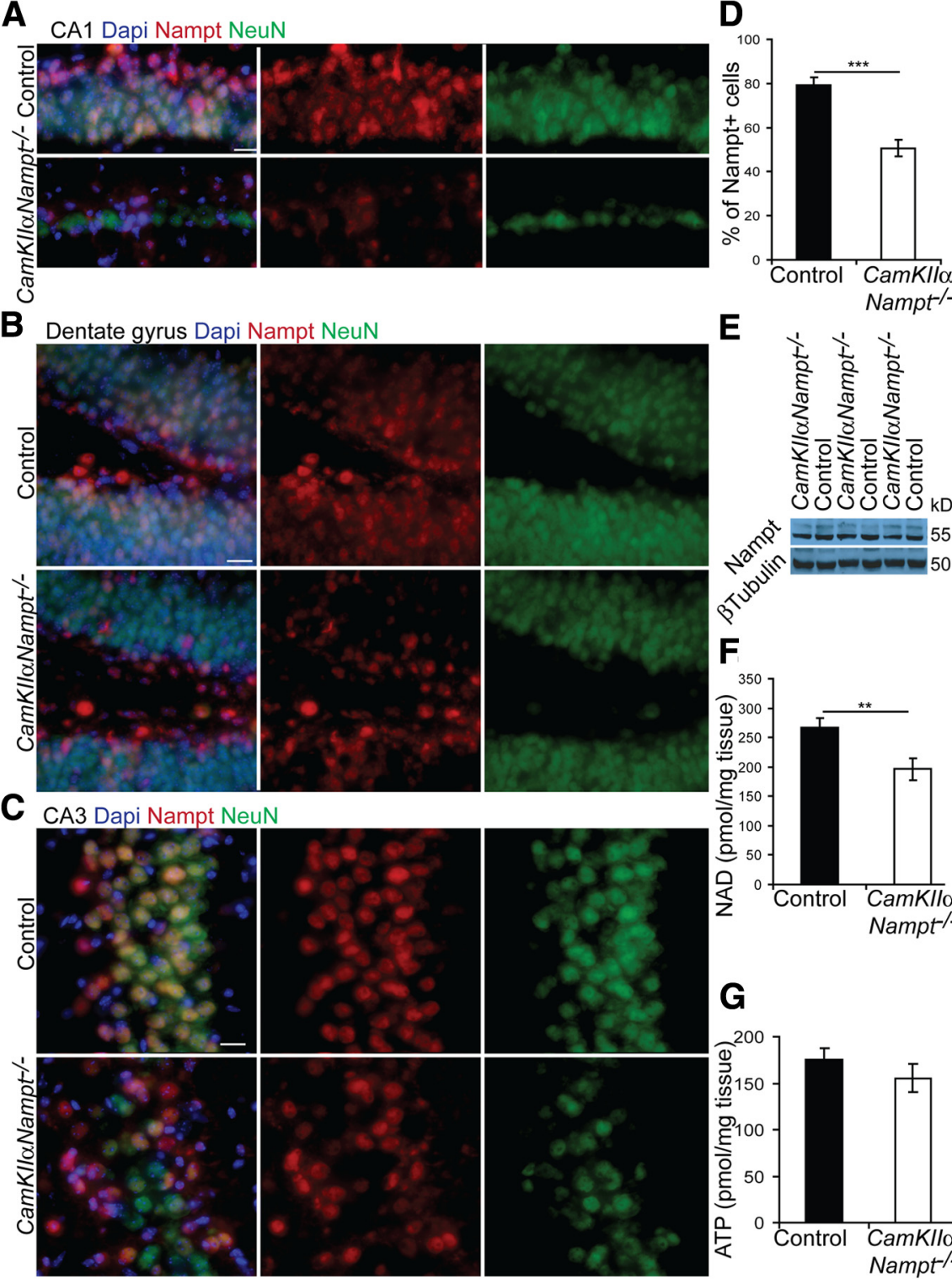

$\mathrm{E}$
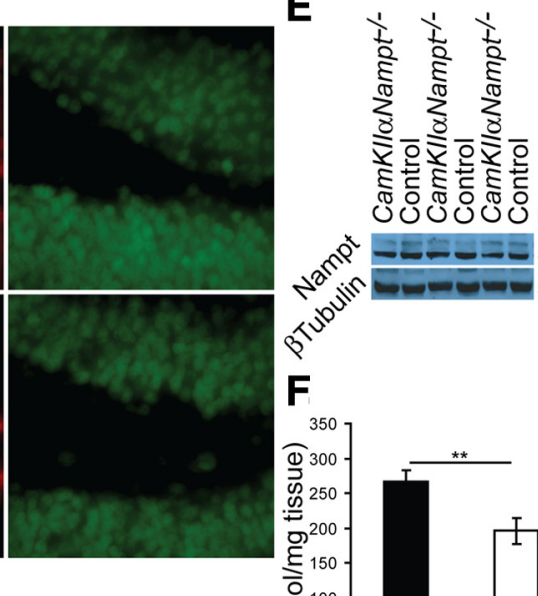

즈는 55

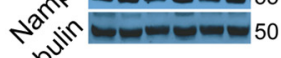

रें

$\mathbf{F}$
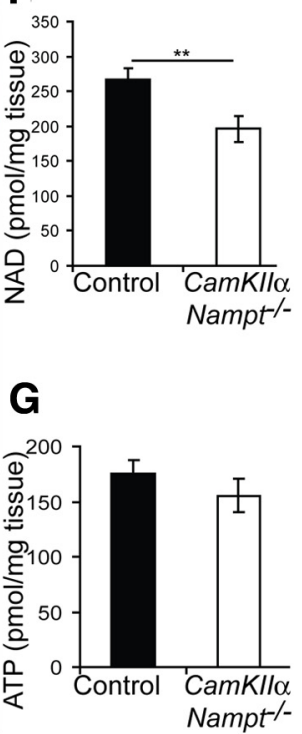

Figure 2. CaMKIl $\alpha \mathrm{Nampt}^{-1-}$ mice show prominent deletion of Nampt and cell loss in CA1 at 2-3 months of age. $\boldsymbol{A}-\boldsymbol{C}$, Representative images of Immunofluorescence for DAPI (blue), Nampt (red), and NeuN (green) in coronal sections $(n=5)$. Scale bars, $20 \mu \mathrm{m}$. In control mice, NeuN ${ }^{+}$neurons express Nampt. This expression is greatly reduced in the DG, CA3, and CA1 of CaMKII $\alpha \mathrm{Nampt}^{-1-}$ mice. D, Quantification of immunohistochemistry in the CA1 stratum pyramidale $(n=5)$. The percentage of $\mathrm{DAPI}^{+}$cells that express Nampt. $\boldsymbol{E}$, Representative immunoblots of hippocampal extracts of CaMKII $\alpha$ Nampt $^{-1-}$ and control mice at 6-7 months of age. $\boldsymbol{F}$, HPLC analysis in hippocampal extracts of CaMKII $\alpha$ Nampt $^{-1-}$ mice $(n=14)$ and control mice $(n=12)$ shows significantly reduced NAD ${ }^{+}$levels. G, HPLC analysis in hippocampal extracts of CaMKII $\alpha$ Nampt ${ }^{-1-}$ and control mice shows similar ATP levels $(n=12)$. Data are presented as mean \pm SEM. ${ }^{*} p<0.05 ;{ }^{* *} p<0.01 ;{ }^{* * *} p<0.001$.

age. Consistent with this notion, immunoblotting for activated caspase 3 failed to detect any differences between 2- and 3-month-old CaMKII $\alpha$ Nampt ${ }^{-1-}$ and control mice (Fig. 3E). To assess autophagy, we determined the formation of LC3B-II, an autophagosome-membrane-associated form of LC3B that correlates with the induction of autophagy. However, immunoblotting for LC3B failed to detect any differences between CaMKII $\alpha \mathrm{Nampt}^{-/-}$mice and control mice in the levels of the LC3B-I and LC3B-II species (Fig. 3E). To assess excitotoxicity, we checked spectrin breakdown products: the $280 \mathrm{kDa}$ spectrin protein can be cleaved to unique 150 and $145 \mathrm{kDa}$ fragments by calpain (Bevers and Neumar, 2008). The $145 \mathrm{kDa}$ product of 


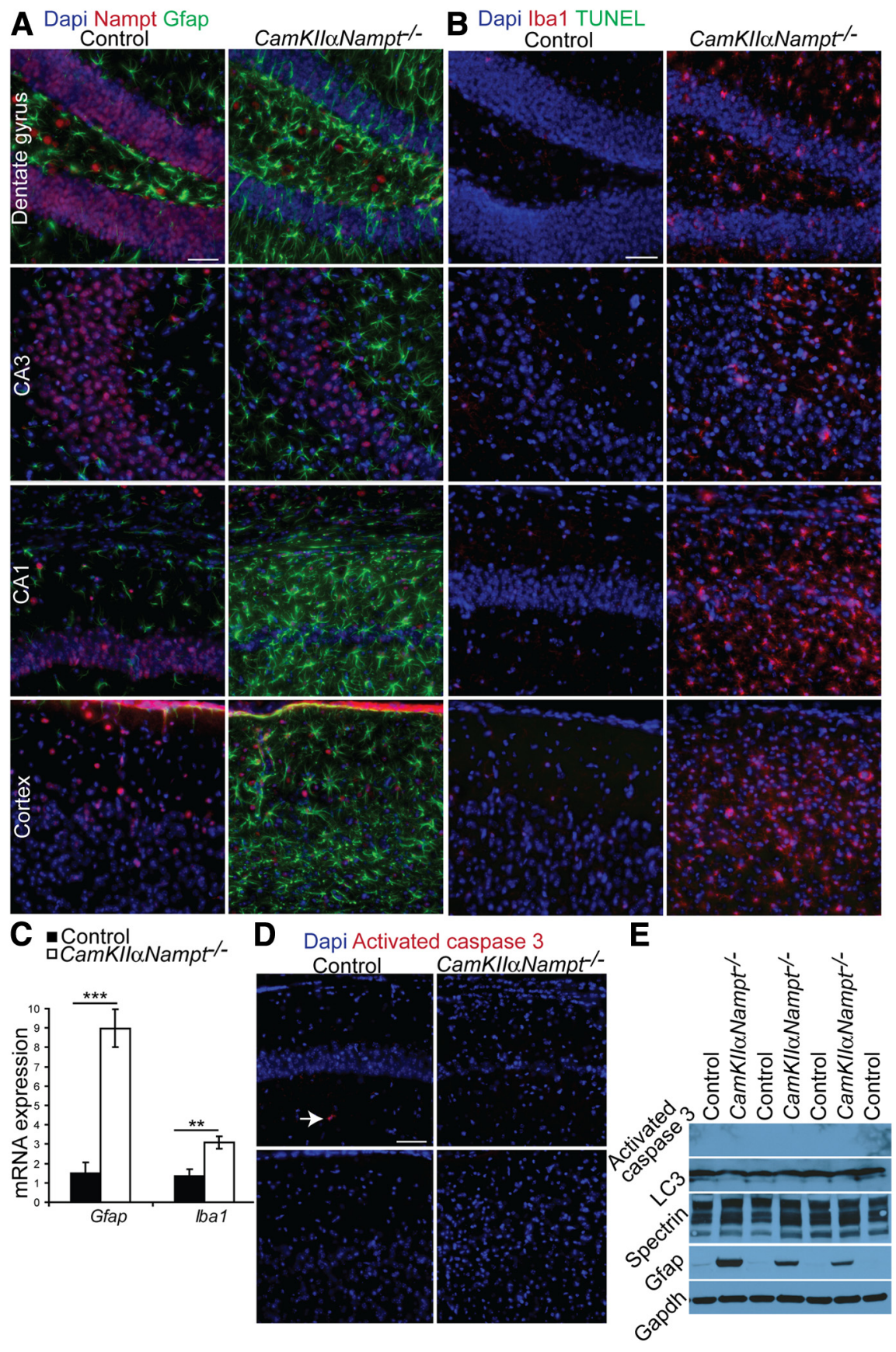

Figure 3. CaMKIl $\alpha \mathrm{Nampt}^{-1-}$ mice show extensive $\mathrm{CA} 1$ and cortical astrogliosis and microgliosis without obvious cell death at $2-3$ months of age. $\boldsymbol{A}, \boldsymbol{B}, \boldsymbol{D}$, Representative images of Immunofluorescence $(n=5-9)$ taken in coronal sections. Scale bars, 50 $\mu \mathrm{M} . \boldsymbol{A}$, Immunofluorescence for DAPI (blue), Nampt (red), and Gfap (green). $\boldsymbol{B}$, Immunofluorescence for DAPI (blue), Iba1 (red), and TUNEL (green). C, Quantitative PCR analysis with hippocampal RNA samples of CaMKII $\alpha N_{N a m p t}{ }^{-1-}$ mice $(n=11)$ and control mice $(n=14)$ shows a 6 -fold increase in Gfap and a 2.3-fold increase in Iba 1 mRNA expression. $\boldsymbol{D}$, Immunofluorescence for DAPI (blue) and activated caspase 3 (red) shows no obvious difference in cell death between CaMKIl $\alpha \mathrm{Nampt}^{-1-}$ mice and controls. Arrow highlights a rare activated caspase $3^{+}$cell. $\boldsymbol{E}$, Representative images of immunoblots in CaMKIl $\alpha$ Nampt ${ }^{-1-}$ mice $(n=4)$ and control mice $(n=5)$ shows a lack of overt cell death (activated caspase 3:17, 19kDa; LC3:17, $19 \mathrm{kDa}$ ) and a slight increase in the 145/150 kDa spectrin (280, 145, 150, $100 \mathrm{kDa}$ ) breakdown product and the presence of astrogliosis (Gfap: $55 \mathrm{kDa}$ ). Immunoblots were normalized by Gapdh (36 kDa). Data are presented as mean \pm SEM. ${ }^{*} p<0.05 ;{ }^{* *} p<0.01 ;{ }^{* * *} p<0.001$.

spectrin appeared to increase in CaMKII $\alpha$ Nampt $t^{-1-}$ mice relative to control mice, implying some calpain activation due to excitotoxicity (Fig. 3E; control mice: $0.73 \pm 0.04$; CaMKII $\alpha$ Nampt $t^{-I-}$ mice: $0.93 \pm 0.06$; Student's $t$ test, $p=$ $0.012, n=9)$. The increase in Gfap gene expression was also seen at the protein level (Fig. 3E).

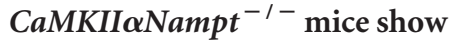
specific CA1 and cortical dendritic loss and swelling but intact expression of synaptic markers at 2-3 months of age Calpain activation is known to result in loss of Map2 immunoreactivity upon injury (Matesic and Lin, 1994; Pettigrew et al., 1996; Minger et al., 1998). Intriguingly, we found that, in CaMKII $\alpha$ Nampt ${ }^{-/-}$mice, CA1 stratum oriens exhibited a complete loss of Map2 staining and the stratum radiatum highlighted a sparse layer of swollen dendrites (Fig. 4A). In contrast, control mice exhibited long, string-like apical and basal Map $2^{+}$dendrites in the stratum radiatum and stratum oriens, respectively (Fig. $4 A$ ), as reported previously (Kitagawa et al., 1989; Kwei et al., 1993; Matesic and Lin, 1994; Folkerts et al., 1998; Jalava et al., 2007). No Map2 immunostaining was found in $\mathrm{DAPI}^{+}$nuclei or in the myelin tracts. Loss of Map2 ${ }^{+}$dendrites upon injury is thought to occur both before and during spectrin degradation by calpain (Matesic and Lin, 1994; Pettigrew et al., 1996; Minger et al., 1998). Therefore, to determine whether the observed changes were specific to Map2, we assessed the localization of this cytoskeletal protein. Spectrin immunoreactivity was indistinguishable between CaMKII $\alpha \mathrm{Nampt}^{-1-}$ and control mice, indicating that, whereas calpain-mediated cleavage of spectrin had increased, its degradation had not (data not shown).

To quantify these changes in dendritic arborization, we performed Golgi-Cox impregnation and Sholl analysis on impregnated cells in CA1's stratum pyramidale. CaMKII $\alpha$ Nampt $^{-/-}$mice showed a reduction in dendritic arborization, with a significant decrease in intersections at multiple distances from the soma (Fig. $4 B, C$; Student's $t$ tests, $p=0.01-0.002, n=$ 4-5 mice, 10 neurons per mouse). This analysis also revealed a drastic reduction in the number of impregnated neurons, suggesting a reduced neuronal population (control mice: $189 \pm 8$ cells $/ \mathrm{mm}^{2}$; CaMKII $\alpha$ Nampt $t^{-/-}$mice: $83 \pm 17$ cells/ $\mathrm{mm}^{2}$; Student's $t$ test, $p=0.0008, n=4-5$ ). Despite these remarkable histological changes, mRNA expression of markers of excitatory neurons (NR1, NR2A, NR2B), synapses (Dlg4), GABAergic signaling (GabaR $\gamma 1$, GabaR $\alpha 2)$, or synaptic plasticity $(B d n f)$ were all similar between 2- and 3-month-old CaMKII $\alpha$ Nampt ${ }^{-1-}$ and control mice (Fig. 4D). Only two immediate early genes (Arc, Egr1) showed significant reduction in their mRNA expression in CaMKII $\alpha \mathrm{Nampt}^{-/-}$mice relative to control mice (Fig. $4 D$; Student's $t$ tests, Arc: $p=0.001, n=$ 11-14; Egrl: $p=0.002, n=11-14)$. 
To determine whether this dendritic abnormality extended to the synapses, we performed immunohistochemistry for synaptophysin, a marker for presynaptic terminals; vesicular glutamate transporter 1 (VGlut1), a marker of glutamatergic synaptic vesicles (Santos et al., 2009); and postsynaptic density protein 95 (PSD95), a marker of excitatory postsynaptic densities (Aarts and Tymianski, 2004) in the stratum radiatum. Surprisingly, the intensity of synaptophysin was overtly normal in CaMKII $\alpha$ Nampt $^{-/-}$mice (Fig. $4 E$ ), confirming no major defects in synaptic protein expression. Consistent with this, and supporting the notion of a CA1specific effect, immunoblotting for Map2 and synaptophysin in hippocampal extracts failed to detect any differences between CaMKII $\alpha \mathrm{Nampt}^{-1-}$ and control mice (Fig. 4F). VGlut1 expression in the hippocampus was significantly higher in CaMKII $\alpha$ Nampt $t^{-1-}$ mice both when assessed by mean intensity (Fig. $4 G$, control mice: mean intentisy $111 \pm 7$ arbitrary units [AU], $n=6$; CaMKII $\alpha \mathrm{Nampt}^{-1-}$ mice: mean intensity $136 \pm 6 \mathrm{AU}, n=7$; Student's $t$ test, $p=0.02$ ) and by the percentage of CA1 area covered by the thresholded VGlut1 immunoreactive signal (control mice: $16 \pm 9 \%$ of CA1 area, $n=6$; CaMKII $\alpha$ Nampt $t^{-1-}$ mice: $49 \pm 9 \%$ of CA1 area, $n=7$; Student's $t$ test, $p=0.02$ ). In contrast, PSD95 expression in the hippocampus trended to decrease in CaMKII $\alpha \mathrm{Nampt}^{-1-}$ mice (mean intensity $85 \pm 4 \mathrm{AU}, n=7$ ) relative to control mice (mean intensity $95 \pm 4 \mathrm{AU}$, Student's $t$ test, $p=0.12, n=6$ ).

Although these normal expression patterns do not confirm correct localization of these proteins, they suggest that CaMKII $\alpha \mathrm{Nampt}^{-1-}$ mice have intact synaptic components. In addition, because VGlut1 expression levels determine the amount of glutamate stored and released per vesicle (Wojcik et al., 2004; Wilson et al., 2005), the increase in VGlut1 expression and decrease in PSD95 expression could indicate an imbalance between presynaptic glutamate release and postsynaptic densities.

CaMKII $\alpha$ Nampt ${ }^{-/-}$mice exhibit altered hippocampal physiology at 2-3 months of age

With such overt effects on dendritic morphology, we suspected that CA1 synaptic function might be altered. To test this possibility, we stimulated the Schaffer collateral inputs in the CA1 region of hippocampal slices from P60 mice. Stimulation of the Schaffer collateral in-

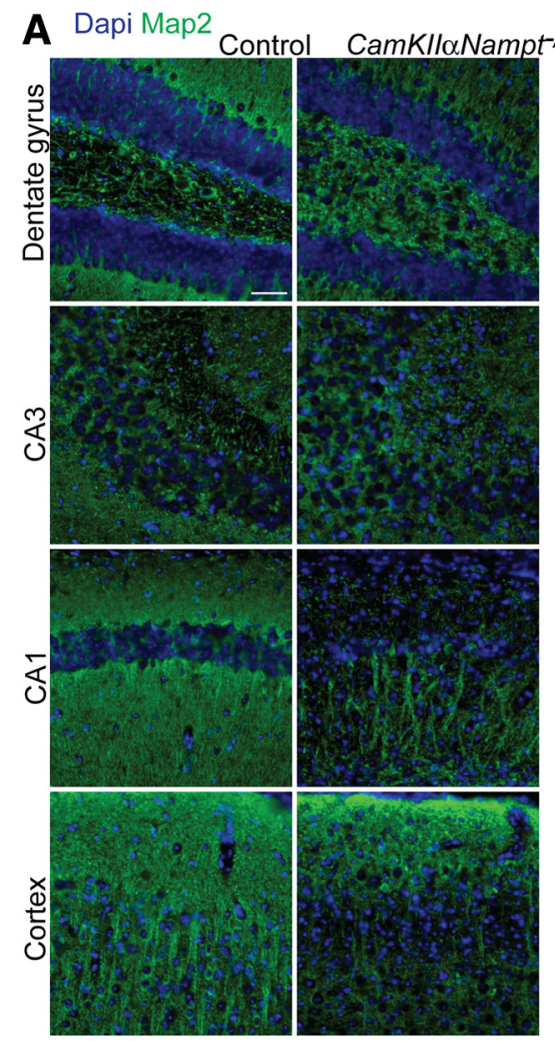

$B$

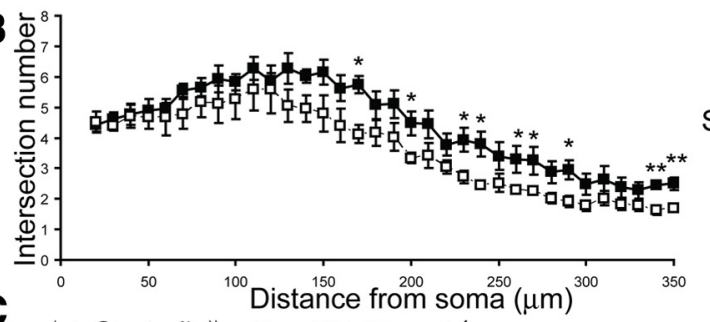

c
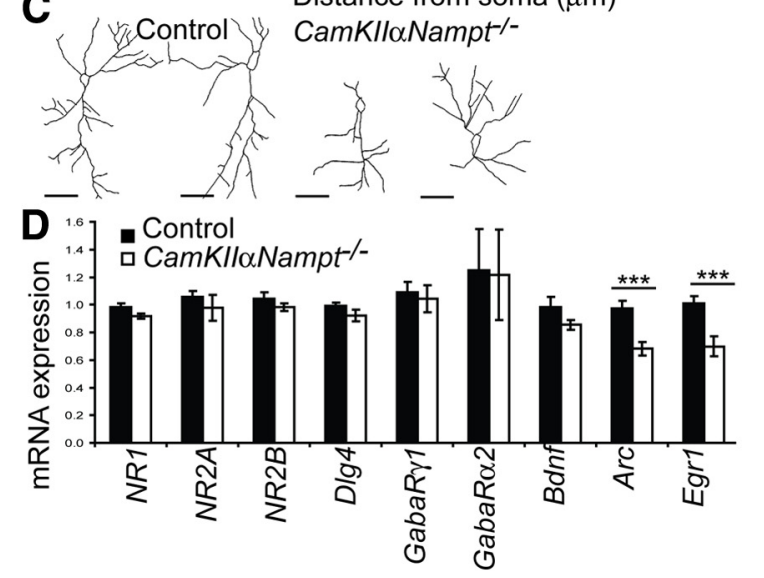

E Dapi Synaptophysin CamKIlaNampt--
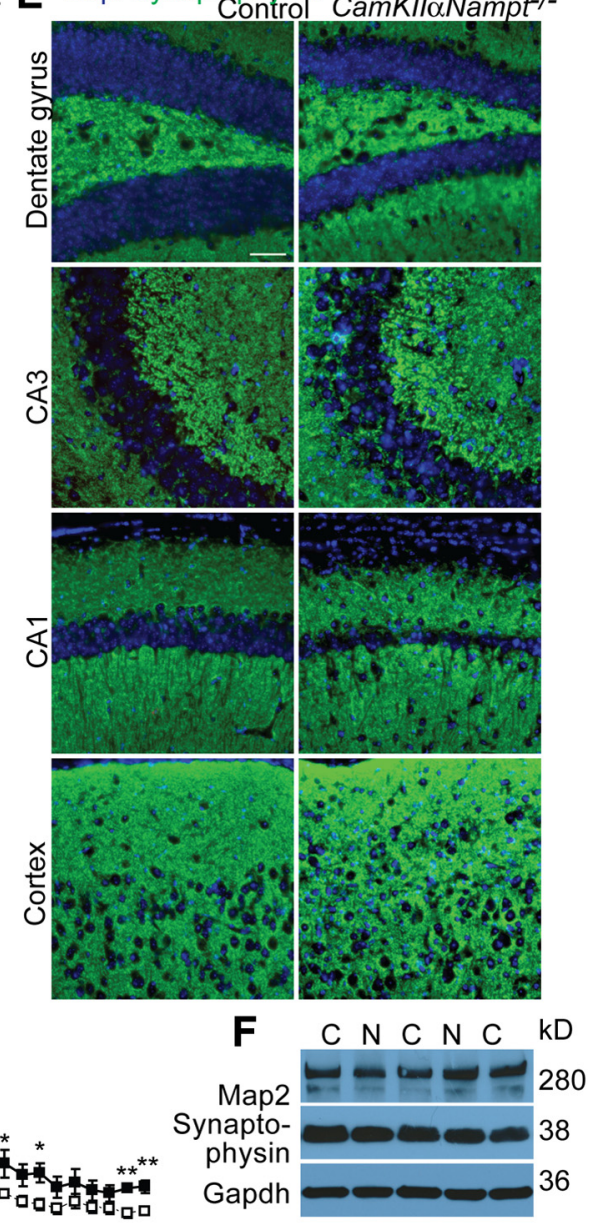

G Dapi VGlut1

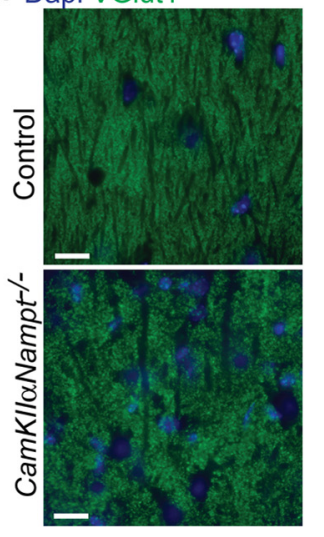

Figure 4. CaMKIl $\alpha \mathrm{Nampt}^{-1-}$ mice show altered dendritic integrity in the absence of overt synapse loss in CA1 at 2-3 months of age. $\boldsymbol{A}$, Representative images of Immunofluorescence for DAPI (blue) and Map2 (green) in control and CaMKII $\alpha$ Nampt ${ }^{-1-}$ coronal sections $(n=5-9)$. Scale bars, $50 \mu \mathrm{m}$. There is a reduction of the number and change in the orientation of CA1 dendrites of CaMKIl $\alpha$ Nampt $^{-1-}$ mice relative to control mice. B, C, Golgi-Cox impregnation of CA1 pyramidal neurons. $B$, Sholl analysis of impregnated CaMKIl $\alpha$ Nampt $^{-1}$ - showed a reduction in dendritic arborization. C, Representative traces of Golgi-Cox impregnation in control and CaMKI/ $\alpha$ Nampt ${ }^{-1-}$ coronal sections $(n=4-5)$. Scale bars, $50 \mu \mathrm{m}$. D, Quantitative PCRanalysis in hippocampal RNA samples of CaMKIl $\alpha$ Nampt ${ }^{-1}$ mice $(n=5-11)$ and control $(n=5-14)$ mice shows no change in markers of excitatory neurons (NR1,NR2A,NR2B), synapses (Dlg4), interneurons (GabaR $\gamma 1$, GabaR $\alpha 2)$, or synaptic plasticity (Bdnf), but a reduction in immediate early genes (Arc, Egr1). $\boldsymbol{E}$, Immunofluorescence for DAPI (blue) and Synaptophysin (green) shows no obvious difference in Synaptophysin intensity between CaMKIl $\alpha \mathrm{Nampt}^{-1-}$ and control mice. Scale bars, $50 \mu \mathrm{m}$. $\boldsymbol{F}$, Representative images of immunoblots in CaMKIl $\alpha$ Nampt ${ }^{-1-}$ mice $(n=4)$ and control mice $(n=5)$ show similar levels of Map2 and Synaptophysin. $C$, Control; N, CaMKII $\alpha \mathrm{Nampt}^{-1-}$. G, Immunofluorescence for DAPI (blue) and VGlut1 (green) shows an increase in VGlut1 intensity in CaMKIl $\alpha \mathrm{Nampt}^{-1-}$ mice. Scale bars, $20 \mu \mathrm{m}$. Data are presented as mean \pm SEM. ${ }^{*} p<0.05 ;{ }^{* *} p<0.01 ;{ }^{* * *} p<0.001$. 

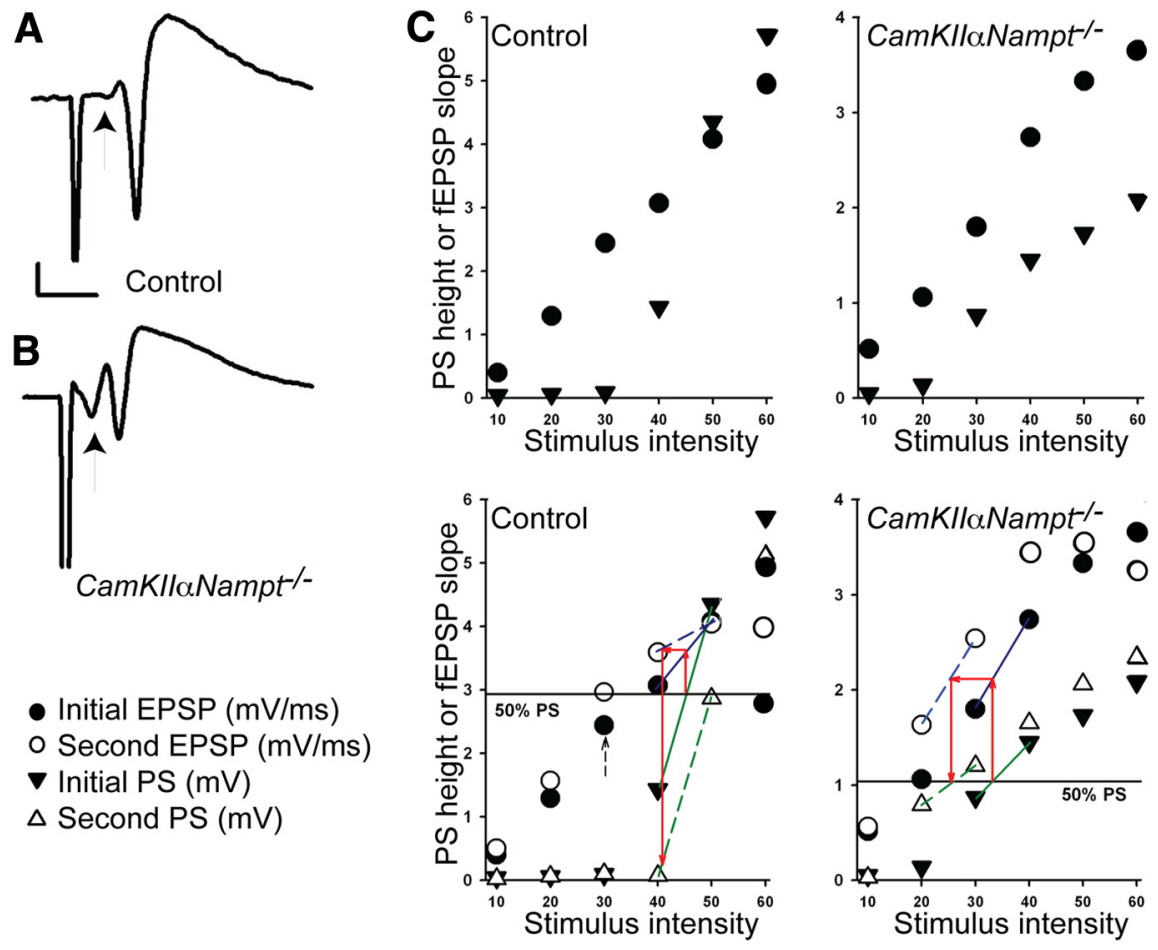

Figure 5. CaMKIl $\alpha \mathrm{Nampt}^{-/-}$mice show altered Schaffer-collateral pathway physiology at 2-3 months of age. $\boldsymbol{A}$, Representative fEPSPs obtained from control mice show a small presynaptic volley (arrow) relative to the population spike $(n=5)$. Calibration: $1 \mathrm{mV}, 5 \mathrm{~ms}$. B, Representative fEPSPs obtained from CaMKIl $\alpha$ Nampt ${ }^{-1}$ - mice show a large presynaptic volley (arrow) relative to the population spike $(n=5)$. C, Assessment of PS amplitude (height) upon paired-pulse stimulation. Because both dendritic fEPSPs and PS height are altered by paired-pulse stimulation, we used an analysis of $I 0$ curves to calculate the size of fEPSP required to generate a half-maximal PS after the first (top) and second (bottom) paired stimuli. The 10 curves of the first stimuli in the top are repeated in the bottom for clarity. The left graphs show typical I0 curves for dendritic fEPSPs (circles) and PSs (triangles) in a slice from a control mouse. The stimulus intensity needed to evoke a half-maximal PS by the first stimulation (top) was determined by the intersection of the horizontal $50 \%$ maximal line with a line connecting the two points straddling the half maximal value (shown by the green solid line between two PS points in black triangles in bottom). We then used this value to calculate the size of dendritic fEPSP required to generate a PS of this magnitude, shown as the intersection of the upward red arrow and the solid blue line connecting two points (black circles), on the initial fEPSP I0 curve. We next calculated the stimulus intensity required for the second (paired) stimulus to induce an equivalent fEPS, shown as a horizontal red arrow intersecting the dotted blue line, from the second pulse fEPSP curve (white circles). At this stimulus intensity, we could then determine the PS amplitude generated by the second stimulation, shown as a downward red arrow intersecting the dotted green line on the second PS curve (white triangle). This analysis shows that the PS generated by a second stimulation at an equivalent fEPSP size is much smaller than the PS produced by the initial stimulus, indicating the presence of significant paired-pulse depression. The right graphs show a similar analysis of 10 curves in a slice from a CaMKII $\alpha N a m p t^{-1-}$ mouse. The marked paired-pulse depression of PS amplitude observed in the control slice is not seen in the CaMKIl $\alpha$ Nampt ${ }^{-1-}$ mouse, despite clear paired-pulse potentiation of dendritic fEPSPs, manifest as a leftward shift in the fEPSP I0 curves (black vs white circles). The dashed arrow in the lower left graph depicts the 50\% maximal fEPSP; this stimulus intensity was used to monitor fEPSPs in LTP studies.

puts reliably evoked fEPSPs and population spikes in control and CaMKII $\alpha \mathrm{Nampt}^{-1-}$ mice. Consistent with the changes we observed in dendritic morphology, however, we found that fEPSPs and population spikes in slices from CaMKII $\alpha \mathrm{Nampt}^{-1-}$ mice consistently required a large presynaptic fiber volley compared with controls (Fig. $5 A, B$ ). We quantified this effect by analyzing the ratio of presynaptic fiber volley amplitude required to evoke a maximal population spike. Although the difference did not reach statistical significance, the ratio of presynaptic volley to maximal population spike was only $4.7 \pm 2.5 \%$ in control mice (Fig. $5 A$ ), consistent with prior work (Bukalo and Dityatev, 2006), whereas the ratio was $110.9 \pm 85.1 \%$ in CaMKII $\alpha \mathrm{Nampt}^{-1-}$ mice (Fig. $5 B$ ). Furthermore, even with maximal stimuli, we consistently observed larger fiber volleys and smaller maximal population spikes in CaMKII $\alpha \mathrm{Nampt}^{-1-}$ mice compared with controls (maximal fiber volleys: control mice: $0.12 \pm 0.05 \mathrm{mV}$; CaMKII $\alpha$ Nampt $t^{-1-}$ mice: $0.78 \pm 0.27 \mathrm{mV}$; Student's $t$ test, $p=$ $0.046, n=5$; maximal population spikes: control mice: $3.67 \pm 0.70 \mathrm{mV}$; CaMKII $\alpha$ Nampt $t^{-1-}$ mice: $1.90 \pm 0.44$ $\mathrm{mV}$; Student's $t$ test, $p=0.07, n=5$ ). These findings indicate that, despite having intact synaptic responses, CaMKII $\alpha$ Nampt $t^{-1-}$ mice have altered inputs into CA1 and diminished somatic excitability in response to synaptic activation.

Presynaptic alterations in the Schaffer collateral pathway can affect paired-pulse plasticity (Capogna, 1998; Nicoll and Malenka, 1999). Therefore, we assessed fEPSPs and population spikes (PSs) of control and CaMKII $\alpha$ Nampt $t^{-1-}$ mice upon paired-pulse stimulation delivered at an interval of $21 \mathrm{~ms}$. To quantify changes in paired-pulse plasticity, we first determined the amplitude of a fEPSP that generated a 50\% maximal PS evoked by the initial stimulation (Fig. $5 C$, top) and then found the size of the second PS generated by the equivalent fEPSP evoked by the second (paired) stimulation (Fig. 5C, bottom). As is typically seen (Capogna, 1998), we observed paired-pulse depression of PSs in control slices after adjusting for the size of dendritic fEPSPs (second PS = $40.3 \pm 18.7 \%$ of initial PS amplitude, $n=6)$. In contrast, slices from CaMKII $\alpha$ Nampt ${ }^{-1-}$ mice did not exhibit similar paired-pulse depression (second PS $=116.6 \pm 11.5 \%$ of initial PS amplitude; Student's $t$ test, $p=0.004, n=$ 7). A typical pattern of paired-pulse PS depression in a slice from a control mouse highlights differences between control (Fig. 5 C, bottom left) and CaMKII $\alpha$ Nampt $t^{-1-}$ mice (Fig. $5 C$, bottom right). These results again support the conclusion that CaMKII $\alpha \mathrm{Nampt}^{-1-}$ mice have altered somatic excitability in response to synaptic inputs.

\section{CaMKII $\mathrm{Nampt}^{-/-}$mice exhibit hyperactivity and mild sensorimotor deficits}

Considering the histological abnormalities observed in 2- to 3-month-old CaMKII $\alpha \mathrm{Nampt}^{-1-}$ mice, we conducted several behavioral analyses to evaluate the possibility that disturbances in hippocampal function could lead to impaired performance on certain behavioral tests. We first conducted a $1 \mathrm{~h}$ locomotor activity test and a battery of sensorimotor measures as general assessments of health and to determine whether certain nonassociative behavioral disturbances were likely to affect learning and memory performance. In the $1 \mathrm{~h}$ locomotor activity test, CaMKII $\alpha \mathrm{Nampt}^{-1-}$ mice exhibited a 2.8- to 3.8-fold increase in ambulations (whole-body movements) over control mice throughout the entire test session (Fig. 6A, B; rmANOVA, genotype effect: $\left.F_{(1,27)}=33.99, p<0.00005\right)$. Significant differ- 
ences were also observed for each time block during the test session (pairwise comparisons, $p<0.0003$ ), but not for main or interaction effects involving sex. Control mice showed habituation over the test period, exhibited by a significant $57 \%$ decrease $(p=0.014)$ in ambulations between blocks 1 and 6 . In contrast, CaMKII $\alpha$ Nampt $t^{-/-}$mice showed only a $22 \%$ decrease in ambulations $(p=0.054)$. In addition, CaMKII $\alpha \mathrm{Nampt}^{-1-}$ mice exhibited a 1.4 - to 2.8 -fold increase in exploratory behavior (instances of vertical rearing) relative to control mice (rmANOVA, genotype effect: $F_{(1,27)}=$ $21.70, p=0.0001)$, in both a sex- and timedependent manner (genotype $\times$ time: $F_{(5,135)}=2.40, p=0.05$, genotype $\times$ sex: $F_{(1,27)}=5.99, p=0.021$, and genotype $\times$ sex $\times$ time: $\left.F_{(5,135)}=3.07, p=0.017\right)$. Specifically, male CaMKII $\alpha$ Nampt $t^{-/-}$mice reared significantly more often than male control mice $\left(F_{(1,27)}=23.06, p=0.0001\right)$, whereas no differences were observed between the groups of female mice (Fig. 6C). As with their ambulations, control mice showed significant habituation of instances of vertical rearing from block 1 to block 6 (53\% decrease; $F_{(1,27)}=25.90, p<$ 0.00005). Conversely, CaMKII $\alpha$ Nampt $t^{-/-}$ mice only showed a nonsignificant $9 \%$ decrease in rearing, suggesting that habituation did not occur. The lack of habituation during activity testing also suggests possible deficits in novelty acquisition or other basic learning and memory capabilities.

To assess possible alterations in emotionality, we compared the activity and exploration levels in the center versus the periphery of the $1 \mathrm{~h}$ locomotor activity test arena. Interestingly, CaMKII $\alpha \mathrm{Nampt}^{- \text {- - }}$ mice made significantly more entries into the center of the test arena (1.8-fold; $\left.F_{(1,27)}=7.08, p=0.013\right)$ and traveled a significantly greater distance in the center (1.9-fold; $\left.F_{(1,27)}=6.00, p=0.021\right)$ than control mice, suggesting a possible decrease in anxiety-like behaviors (Fig. 6D,E). However, because CaMKII $\alpha$ Nampt ${ }^{-1-}$ and control mice did not differ in terms of the percentage of time spent in the center (Fig. 6F) and because CaMKII $\alpha$ Nampt $t^{-1-}$ mice traveled a significantly greater distance (Figure $6 G ; F_{(1,27)}=29.31, p<0.00005$ ) and percentage of distance (Fig. $6 H$ ) in the peripheral zone of the arena, we cannot exclude the possibility that differences observed in the "center" variables are primarily due to the hyperactivity of the CaMKII $\alpha$ Nampt $t^{-1-}$ mice rather than an alteration in emotionality. In these "emotionality" variables, we did not find any significant effects involving sex.

In the sensorimotor battery, CaMKII $\alpha \mathrm{Nampt}^{-l^{-}}$mice exhibited performance deficits on three of seven of the tests com-
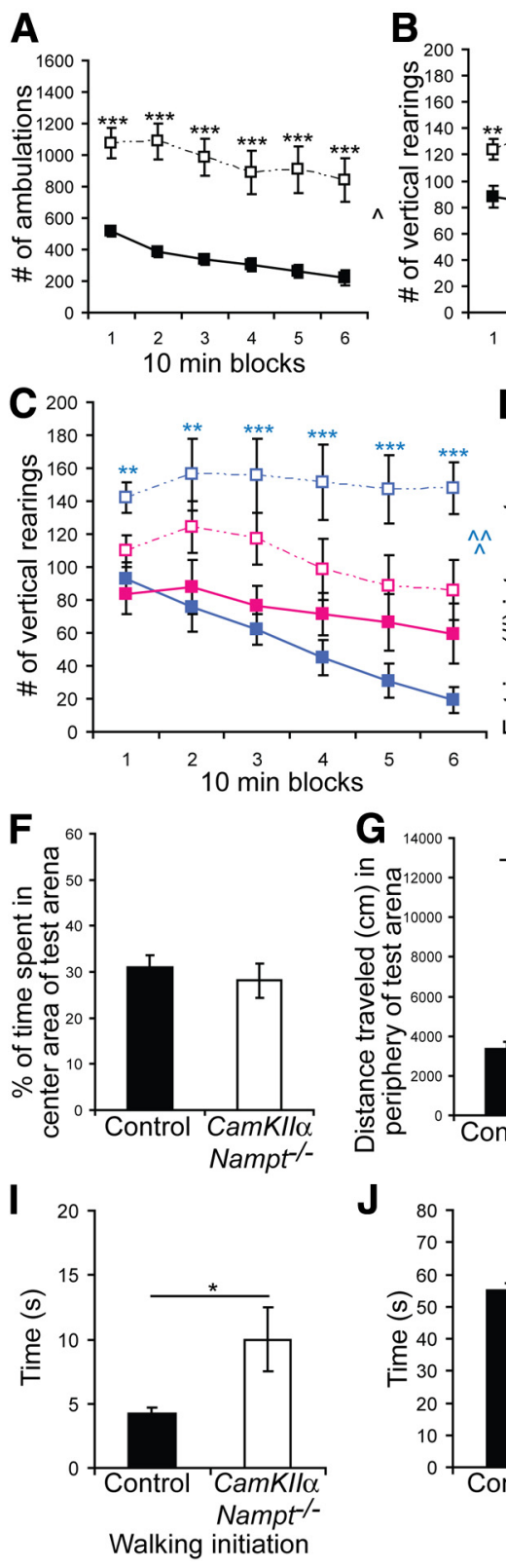

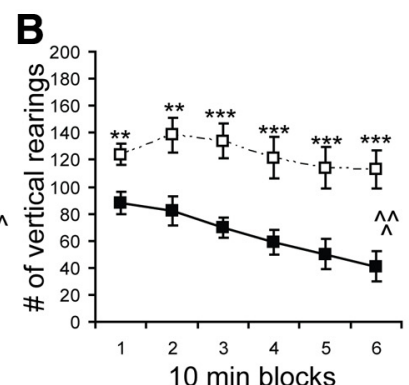

D

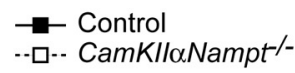

$\rightarrow-M$ Control

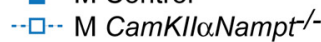

----- F CamKI/lNampt/-
$\rightarrow-\mathrm{F}$ Control

Figure 6. CaMKII $\alpha$ Nampt ${ }^{-1-}$ mice exhibit hyperactivity in the absence of major sensorimotor deficits at $2-3$ months of age. $\boldsymbol{A}-\boldsymbol{E}$, Evaluation of CaMKIll $\alpha \mathrm{Nampt} t^{-1-}$ mice $(n=15)$ and control mice $(n=16)$ on the $1 \mathrm{~h}$ locomotor test. CaMKIl $\alpha$ Nampt ${ }^{-1-}$ mice showed a much higher average number of ambulations $(\boldsymbol{A})$ and instances of vertical rearing $(\boldsymbol{B})$ in each of the six $10 \mathrm{~min}$ blocks of the testing period than did control mice. $C$, Differences between genotypes in levels of vertical rearing are more pronounced in

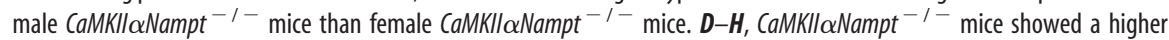
number of entries into the center of the test arena $(\boldsymbol{D})$ and average distance traveled in both the center $(\boldsymbol{E})$ and the periphery of the test arena $(\boldsymbol{G})$ than control mice. The percentage of time spent in the center was similar between genotypes $(\boldsymbol{F})$, whereas the percentage of distance spent in the periphery was higher in CaMKII $\alpha$ Nampt ${ }^{-1-}$ mice $(\boldsymbol{H})$. I- $\boldsymbol{K}$, Evaluation of CaMKII $\alpha$ Nampt ${ }^{-1-}$ mice $(n=15)$ and control mice $(n=16)$ on a battery of sensorimotor tests. CaMKIll $\alpha$ Nampt ${ }^{-1-}$ mice showed increased time to initiate walking (movement) out of a square $(I)$, decreased time to balance on a ledge $(J)$, and increased time to climb down a pole $(\boldsymbol{K})$. Asterisks represent significance generated from unpaired Student's $t$ tests. $\wedge$ and $\wedge \wedge$ represent significance generated from rmANOVAs. Data are presented as mean \pm SEM. ${ }^{*} p<0.05 ;{ }^{* *} p<0.01 ;{ }^{* * *} p<0.001$.

pared with control mice. Specifically, CaMKII $\alpha$ Nampt ${ }^{-1-}$ mice were not impaired on the platform, the $90^{\circ}$ inclined screen, or the inverted screen tests (data not shown). However, they took significantly longer to move out of a small circumscribed area (square) during the walking initiation test $\left(2.3\right.$-fold; $F_{(1,27)}=$ $4.68, p=0.040)$, remained on an elevated ledge for a significantly less time $\left(40 \% ; F_{(1,27)}=30.14, p<0.00005\right)$, and took significantly longer to climb down a pole $\left(2.4\right.$-fold; $F_{(1,27)}=$ 

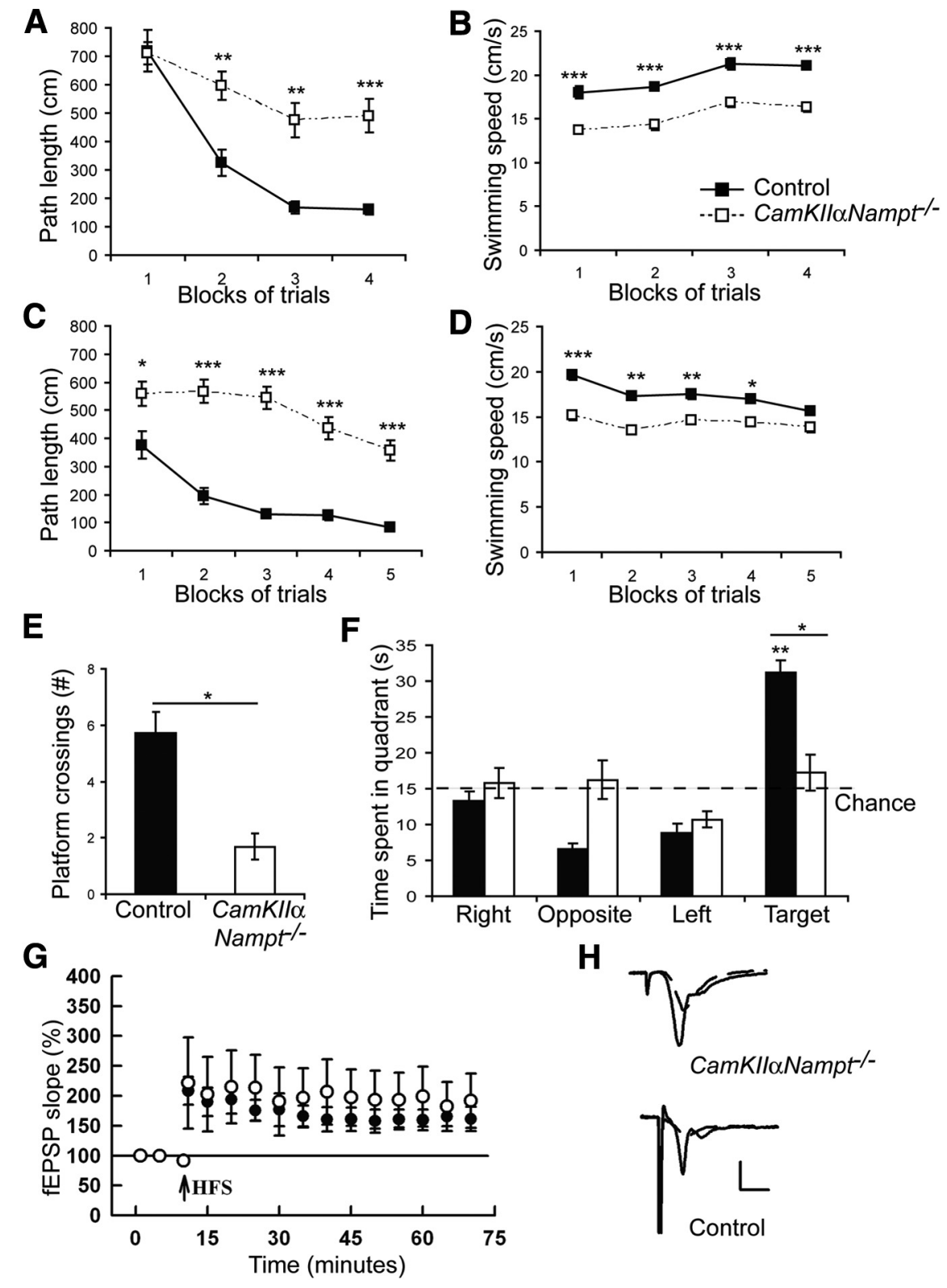

CamKIlaNampt/-

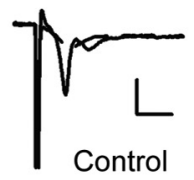

Figure 7. CaMKII $\alpha \mathrm{Nampt}^{-1-}$ mice show impairments in hippocampal-dependent learning and memory, but not LTP, at 2-3 months of age. $\boldsymbol{A}-\boldsymbol{F}$, Evaluation of CaMKII $\alpha$ Nampt ${ }^{-1-}$ mice $(n=15)$ and control mice $(n=16)$ on the MWM. During both the cued $(\boldsymbol{A})$ and place $(\boldsymbol{C})$ conditions of the MWM, CaMKIl $\alpha \mathrm{Nampt}^{-1-}$ mice exhibited significantly longer path lengths to find the platform relative to control mice. The swimming speed of CaMKIl $\alpha \mathrm{Nampt}^{-1-}$ mice was significantly lower than control mice in during acquisition of the cued $(\boldsymbol{B})$ and the place $(\boldsymbol{D})$ conditions of the MWM. During the probe condition of the MWM, CaMKIl $\alpha$ Nampt ${ }^{-1-}$ mice exhibited significantly fewer platform crossings $(\boldsymbol{E})$ and less time $(\boldsymbol{F})$ in the target quadrant relative to control mice. G, CaMKIl $\alpha$ Nampt $^{-1-}$ mice $(n=7)$ and control mice $(n=6)$ exhibit similar LTP at P60. $\boldsymbol{H}$, Representative fEPSP traces for CaMKII $\alpha$ Nampt $^{-1-}$ mice (top) and control mice (bottom). Calibration: $1 \mathrm{mV}, 5 \mathrm{~ms}$. Data are presented as mean \pm SEM. ${ }^{*} p<0.05 ;{ }^{* *} p<0.01 ;{ }^{* * *} p<0.001$.

19.82, $p=0.0001)$ than controls (Fig. $6 I-K)$. These results suggest that CaMKII $\alpha$ Nampt ${ }^{-1-}$ mice have mild sensorimotor impairments in terms of speed to movement, coordination between the forelimbs and hindlimbs, and balance compared with control mice.

CaMKII $\alpha \mathrm{Nampt}^{-/-}$mice show impaired spatial cognition in the MWM

To assess spatial learning and memory, we next evaluated CaMKII $\alpha$ Nampt $^{-1-}$ and control mice on the MWM. In the cued trials of the MWM, CaMKII $\alpha$ Nampt ${ }^{-1-}$ and control mice ini- tially showed equivalent performance levels with regard to escape path length (Fig. $7 A$ ). However, control mice rapidly improved their performance in the subsequent three blocks of trials such that their performance became far superior to that of CaMKII $\alpha$ Nampt ${ }^{-1-}$ mice during the rest of training (rmANOVA, genotype effect: $F_{(1,27)}=17.18, p=0.0003$; genotype $\times$ blocks of trials interaction: $F_{(3,81)}$ $=5.71, p=0.001$ ). Indeed, CaMKII $\alpha$ Nampt ${ }^{-1-}$ mice exhibited significantly greater path lengths relative to the control group during blocks 2-4 (pairwise comparisons, $p<0.003$ ). However, both CaMKII $\alpha \mathrm{Nampt}^{-1-}$ and control mice showed a significant decrease in path length, or improved performance, from block 1 to block $4\left(F_{(1,27)}=11.93, p=0.002\right.$; and $F_{(1,27)}$ $=72.11, p<0.00005$, respectively), suggesting that some cued learning occurred even in CaMKII $\alpha \mathrm{Nampt}^{-1-}$ mice. CaMKII $\alpha$ Nampt ${ }^{-1-}$ mice also exhibited significantly slower swimming speeds on average across blocks of trials relative to control mice (Figure $7 B ; 22 \%$ decrease; rmANOVA, genotype effect: $\left.F_{(1,27)}=46.21, p<0.00005\right)$ and for each block of trials (pairwise comparisons, $p<0.0002$ ). Because escape latency is directly affected and confounded by differences in swimming speeds, the significantly slower swimming speeds in CaMKII $\alpha$ Nampt ${ }^{-1-}$ mice make escape latency an inappropriate variable to assess performance. Therefore, the latency data are not presented here. No significant effects involving sex were found during the cued trials.

During acquisition training in the place (spatial learning) condition of the MWM, performance differences between the groups became even greater. Across all trial blocks, CaMKII $\alpha$ Nampt ${ }^{-1-}$ mice showed much longer path lengths than control mice (Figure 7C; rmANOVAs, genotype $F_{(1,27)}=72.16, p<0.00005$; genotype $\times$ blocks of trials interaction $F_{(4,108)}$ $=3.11, p=0.034)$. The performance of CaMKII $\alpha$ Nampt ${ }^{-1-}$ mice was significantly impaired for blocks 2-4 (pairwise comparisons, beyond Bonferroni correction, $p<0.00005)$, whereas large differences were also observed for block 1 $\left(F_{(1,27)}=6.71, p=0.015\right)$. Specifically, CaMKII $\alpha$ Nampt $t^{-1-}$ mice initially showed a 1.5 -fold longer path length in block 1 that increased to 4.2-fold in block $5\left(F_{(1,27)}=9.58, p=0.005\right.$, and $F_{(1,27)}=19.18, p=0.0002$, respectively). However, as in the cued trials, both groups showed some evidence of spatial learning, although the performance of control mice was far superior. Again, as in the cued trials, the CaMKII $\alpha N_{a m p t^{-1-}}$ mice also exhibited significantly decreased swimming speeds (Figure $7 D$; $18 \%$ decrease, genotype effect: $\left.F_{(1,27)}=14.93, p=0.0006\right)$, although this was dependent on the blocks of trials (genotype $X$ blocks of trials interaction: $\left.F_{(4,108)}=2.79, p=0.030\right)$. 
CaMKII $\alpha$ Nampt $t^{-/-}$mice swam significantly slower than control mice for blocks 1-3 (pairwise comparisons, $p<$ 0.008 ), although differences were also observed during block 4 (pairwise comparison, $p=0.015$ ). Consistent with the poor acquisition performance during the place trials, CaMKII $\alpha \mathrm{Nampt}^{-1-}$ mice also exhibited retention deficits during the probe trial in terms of platform crossings (Figure $7 E$; genotype effect: $F_{(1,27)}=20.89$, $p=0.0001)$ and time spent in the target quadrant (Figure $7 F$; genotype effect: $\left.F_{(1,27)}=19.04 \cdot p=0.0002\right)$. Importantly, control mice showed a spatial bias for the target quadrant by spending significantly more in that quadrant versus the times spent in each of the other quadrants $(p<$ 0.00005), whereas CaMKII $\alpha$ Nampt $t^{-1-}$ mice showed no such bias. Similar to the results from the cued condition of the MWM, no effects involving sex were found for any of the variables from the place or probe trials.

Based on the performance deficits exhibited by CaMKII $\alpha \mathrm{Nampt}^{-/-}$mice during the cued trials, we investigated the possibility that CaMKII $\alpha$ Nampt $t^{-/-}$mice may have had visual impairments that compromised their ability to see proximal and distal cues during MWM testing. However, imaging their retinas revealed no gross defects relative to controls (data not shown). In addition, assessment of visual acuity (grating) thresholds by quantifying optokinetic tracking behavior and evaluation of the photopic and scotopic waves by electroretinography did not reveal any differences between CaMKII $\alpha \mathrm{Nampt}^{-{ }^{-}-}$and control mice (data not shown).

Given the major impairments in spatial learning and memory that CaMKII $\alpha \mathrm{Nampt}^{- \text {- }}$ mice displayed in all conditions of the MWM, we suspected that there would be accompanying impairments in hippocampal synaptic plasticity. Using a half maximal fEPSP stimulus, we assessed LTP in P60 mice. To our surprise, LTP in response to a single $100 \mathrm{~Hz} \times 1 \mathrm{~s}$ HFS was not significantly different between groups (Fig. $7 G$ ). In control mice, HFS resulted in an increase in fEPSP slopes that was $189.5 \pm 23.1 \%$ of baseline measured 60 min after HFS. In CaMKII $\alpha$ Nampt $t^{-1-}$ mice, the fEPSP slopes were $165.0 \pm 18.5 \%$ of baseline (Fig. $7 H$; Student's $t$ test, $p=0.43, n=5$ ).

\section{CaMKII $\alpha$ Nampt $t^{-/-}$mice perform abnormally on the conditioned fear test}

With these major spatial learning and memory deficits, we next addressed the possibility that CaMKII $\alpha \mathrm{Nampt}^{-1-}$ mice also had cognitive deficits in nonspatial forms of learning and memory by evaluating the mice on the conditioned fear test. Analysis of the baseline freezing data collected during the first 2 min of day 1 of conditioned fear testing did not reveal any significant effects involving genotype or sex (Fig. $8 A$ ). In contrast, the freezing data during the training trials when a tone (CS) was paired with a foot shock (US) on day 1 revealed significantly higher levels of freezing in control mice, although this was somewhat depen-

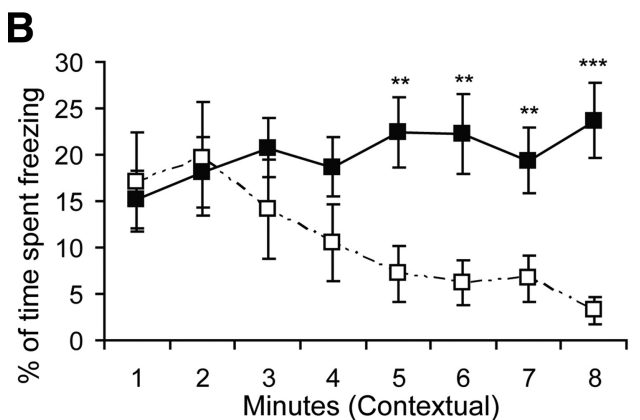

D

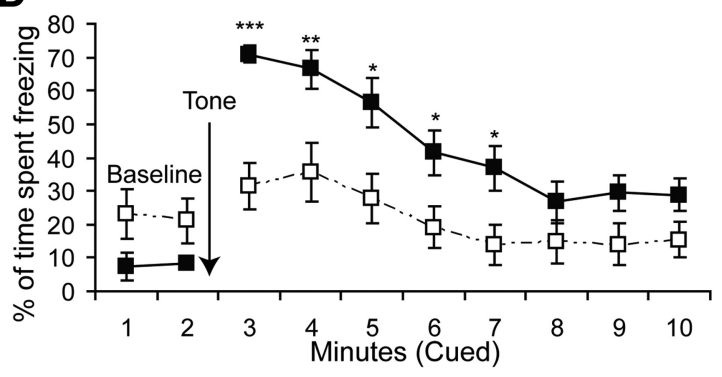

Figure 8. CaMKIl $\alpha \mathrm{Nampt}^{-1-}$ mice show impairments in nonspatial hippocampal-dependent learning and memory at 2-3 mice froze significantly less both before and in response to the tone stimulus. Data are presented as mean \pm SEM. ${ }^{*} p<0.05$

dent on the minutes of the test and sex (rmANOVAs, genotype effect: $F_{(1,27)}=41.02, p<0.00005$; genotype $\times$ sex: $F_{(1,27)}=$ 4.27, $p=0.048$; genotype by minutes: $F_{(2,54)}=11.22, p=$ $0.0001)$. Control mice also froze significantly more often than CaMKII $\alpha$ Nampt $t^{-1-}$ mice during each minute of the tone/ shock (T/S) training (pairwise comparisons, $p<0.003$ ). On average, across minutes during the T/S training, the freezing levels of male and female CaMKII $\alpha \mathrm{Nampt}^{-/-}$mice were significantly lower than their respective controls (genotype $\times$ sex: $F_{(1,27)}=10.90, p=0.003$; genotype $\times$ sex: $F_{(1,27)}=32.77$, $p<0.00005$, respectively).

During the first 2 min of the contextual fear test conducted on day 2, CaMKII $\alpha$ Nampt $t^{-1-}$ and control mice exhibited similar levels of freezing. However, the freezing levels in CaMKII $\alpha \mathrm{Nampt}^{-/-}$mice subsequently dropped precipitously, whereas the levels of control mice remained the same or slightly increased across the test session, resulting in large differences between the groups for minutes 5-8 (Figure $8 B$; rmANOVAs, genotype effect: $F_{(1,27)}=5.91, p=0.022$; genotype $\times$ minutes interaction: $\left.F_{(7,189)}=3.68, p=0.014\right)$. Specifically, the freezing levels of the control mice were significantly greater than those of CaMKII $\alpha \mathrm{Nampt}^{-1-}$ mice for minutes 5-8 (pairwise comparisons, $p<0.0005$ ). To assess levels of conditioning produced by the training on day 1 , we also conducted an additional analysis comparing the average freezing levels during the 2 min baseline on day 1 with the average freezing levels quantified during the first 2 min of contextual fear testing on day 2 (Fig. $8 C$ ). These first 2 min on day 1 and day 2 were significantly different from each 
other (averaged trials: $\left.F_{(1,27)}=26.50, p<0.00005\right)$. However, control and CaMKII $\alpha \mathrm{Nampt}^{-1-}$ mice each showed significantly increased freezing levels across the two test days $\left(F_{(1,27)}=11.42\right.$, $p=0.002$, and $F_{(1,27)}=15.28, p=0.006$, respectively), suggesting that equivalent levels of conditioning occurred in both groups. This is an interesting finding considering the large differences that were observed between the groups during the T/S training on day 1. It may be that the two groups showed approximately equivalent degrees of contextual fear conditioning, but the precipitous drop in freezing of CaMKII $\alpha \mathrm{Nampt}^{-{ }^{-}}$mice reflected their difficulty in maintaining high levels of freezing given their proclivity toward hyperactivity.

Surprisingly, during the altered context baseline testing on day 3 (minutes 1-2), the freezing levels of CaMKII $\alpha \mathrm{Nampt}^{-1-}$ mice were significantly higher than those of controls (Figure $8 D$; genotype effect: $\left.F_{(1,27)}=5.03, p=0.033\right)$, although the magnitude of differences were similar for minutes $1(p=0.045)$ and $2(p=$ 0.044 ). In contrast to the altered context baseline period, control mice exhibited greatly increased freezing levels relative to the CaMKII $\alpha \mathrm{Nampt}^{-1-}$ mice during the auditory cue test. These differences became less prominent as the mice habituated to the tone over the test session (rmANOVAs, genotype effect: $F_{(1,27)}=9.47$, $p=0.005$; genotype by minutes interaction: $F_{(7,189)}=2.85, p=$ $0.012)$. Differences were significant beyond Bonferonni correction $(p=0.05 / 8=0.0063)$ during minute $3(p<0.00005)$, although large differences were also observed during minutes 4 $(p=0.009), 5(p=0.017), 6(p=0.026)$, and $7(p=0.018)$. There were no significant effects involving sex (rmANOVAs) for any of the data from the contextual fear test (day 2) or the altered context baseline or auditory cue test (day 3 ).

Given this impressive lack of freezing, we wondered whether CaMKII $\alpha$ Nampt $t^{-1-}$ mice were able to feel the shock and hear the tone. Therefore, after completion of the conditioned fear testing, we also evaluated the mice for their sensitivity to shock. However, the shock sensitivity of control and CaMKII $\alpha$ Nampt $t^{-1-}$ mice did not reveal any significant differences between groups with regard to the levels of shock that elicited flinching, vocalizing, or running (data not shown). Thus, the differences in performance levels between the two groups during the contextual fear and auditory cue tests were not likely due to differences in shock sensitivity. We also confirmed that none of the control or CaMKII $\alpha \mathrm{Nampt}^{-1-}$ mice was deaf or severely hearing impaired, nor did any of them have sensorimotor deficits that prevented them from displaying normal startle magnitudes in response to loud tones (data not shown).

In summary, CaMKII $\alpha$ Nampt $t^{-1-}$ mice exhibited lower levels of freezing compared with control mice during several phases of the conditioned fear test, including $\mathrm{T} / \mathrm{S}$ training, the middle and later portions of the contextual fear test (day 2), and the early and middle portions of the auditory cue test (day 3 ). Despite their tendency to exhibit low levels of freezing, CaMKII $\alpha$ Nampt $t^{-1-}$ mice still showed some signs of contextual fear conditioning during the early period of the test session on day 2 , when their freezing levels were equivalent to those of control mice.

\section{CaMKII $\alpha \mathrm{Nampt}^{-1-}$ mice exhibit decreased levels of anxiety-} like behaviors

CaMKII $\alpha \mathrm{Nampt}^{-1-}$ mice showed some evidence of altered emotionality, in terms of fear or anxiety-like behaviors, during the $1 \mathrm{~h}$ locomotor activity test, as indexed by an increase in the number of entries into, and the distance traveled in, the center of the test arena compared with control mice (Fig. 6). However, this interpretation was confounded by the hyperactivity of
CaMKII $\alpha \mathrm{Nampt}^{-1-}$ mice. Therefore, to determine whether CaMKII $\alpha \mathrm{Nampt}^{-1-}$ mice exhibit abnormal levels of anxietylike behaviors, we evaluated an independent cohort of naive CaMKII $\alpha \mathrm{Nampt}^{-1-}$ and control mice on the EPM. In the EPM, CaMKII $\alpha \mathrm{Nampt}^{-1-}$ mice displayed decreased levels of anxietylike behaviors relative to the control mice in terms of the classic variables of entries made, time spent, and distance traveled in the open arms (Fig. 9A-C). Specifically, CaMKII $\alpha \mathrm{Nampt}^{-1-}$ mice traveled significantly greater distances in the open arms compared with controls (Figure 9A; rmANOVA, genotype effect: $F_{(1,23)}=18.55, p=0.0003$; genotype $\times$ test day interaction: $\left.F_{(2,46)}=6.78, p=0.006\right)$. Significant differences were found on test days 1 (pairwise comparison, $p=0.0001$ ) and 3 (pairwise comparison, $p=0.008$ ), with large differences also observed on day $2(p=0.034)$. Similar results were found with regard to time spent in the open arms (Figure 9B; genotype effect: $F_{(1,23)}=$ $20.75, p=0.0001)$, in which significant differences were observed on test day $1(p<0.00005)$, although differences were also observed on days $2(p=0.033)$ and $3(p=0.030)$. Last, CaMKII $\alpha \mathrm{Nampt}^{-1-}$ mice also made significantly more entries into the open arms compared with control mice, with the largest differences observed on test day 3 (Figure $9 C$; genotype effect: $\left.F_{(1,23)}=9.84, p=0.005\right)$.

We also analyzed the three aforementioned open arm variables after normalizing values to reflect percentages that were calculated with reference to the totals measured in both sets of arms to counteract any differences in activity that might affect the results. Analyzing these data produced very similar results to those described in the previous paragraph, providing additional evidence that the CaMKII $\alpha \mathrm{Nampt}^{-1-}$ mice displayed decreased levels of anxiety-like behaviors. Specifically, CaMKII $\alpha$ Nampt $t^{-1-}$ mice traveled a significantly greater percentage of distance the open arms out of the total distance traveled compared with control mice on average across the 3 test days ( $r$ ANOVA, genotype effect: $F_{(1,23)}=16.15, p=0.0005$ ), with significant differences on test day 1 (Fig. $9 D$; pairwise comparison, $p=$ 0.0002). Similarly, CaMKII $\alpha$ Nampt ${ }^{-1-}$ mice spent a significantly greater percentage of time in the open arms relative to the total time spent in all of the arms compared with control mice (Figure 9E; genotype effects: $\left.F_{(1,23)}=18.07, p=0.0003\right)$, with significant group differences being observed for test day $1(p=0.0001)$ and large differences found for days $2(p=0.046)$ and $3(p=0.027)$. Last, CaMKII $\alpha$ Nampt $t^{-1-}$ mice had a significantly higher percentage of entries made into the open arms out of the total number of arm entries on average across test days compared with control mice (Figure $9 F$; genotype effect: $\left.F_{(1,23)}=8.44, p=0.0008\right)$, with the largest differences being observed on day $1(p=0.024)$.

Although CaMKII $\alpha \mathrm{Nampt}^{-1-}$ mice traveled longer distances in the open arms of the EPM than control mice, the two groups did not differ in the distance traveled in the relatively safe confines of the closed arms (Fig. 9G). CaMKII $\alpha \mathrm{Nampt}^{-1-}$ mice actually traveled a significantly shorter distance in the center area compared with control mice (genotype effect: $F_{(1,23)}=8.04, p=$ 0.009 ; genotype $\times$ test day interaction: $\left.F_{(2,46)}=8.78, p=0.001\right)$, with significant differences being found for day $1(p=0.002)$ and large differences observed for day 2 (Fig. $9 H ; p=0.032$ ). However, the two groups did not differ in the total distance traveled throughout the EPM, thus providing additional evidence that CaMKII $\alpha$ Nampt $t^{-1-}$ mice exhibit abnormally low levels of anxiety-like behaviors that are not dependent on differences in general ambulatory activity (Fig. 9I). No significant overall effects involving sex were found from any of the rmANOVAs conducted on the above-mentioned EPM variables. In conclu- 
sion, CaMKII $\alpha \mathrm{Nampt}^{-1-}$ mice exhibited decreased anxiety-like behaviors in the EPM. Although the most parsimonious interpretation of the data is that CaMKII $\alpha \mathrm{Nampt}^{-1-}$ mice have lower levels of an emotional state that may be analogous to "anxiety," their poor performance on the MWM raises the possibility that these mice may have a diminished cognitive capacity to detect threatening situations and thus do not respond like control mice under such circumstances.

\section{Discussion}

In this study, we tested the importance of intracellular $\mathrm{NAD}^{+}$biosynthesis from nicotinamide by generating mice lacking a key $\mathrm{NAD}^{+}$biosynthetic enzyme, Nampt, in forebrain excitatory neurons. We show that CaMKII $\alpha$ Nampt $t^{-/-}$mice develop hippocampal and cortical atrophy, astrogliosis, microgliosis, and aberrant dendritic morphology by 2-3 months of age. These histological changes were associated with altered intrahippocampal connectivity and abnormal behavior. Therefore, intracellular Nampt-mediated $\mathrm{NAD}^{+}$biosynthesis is the primary source of $\mathrm{NAD}^{+}$for forebrain excitatory neurons and is critical for neuronal function and survival.

Consistent with the established features of CaMKII $\alpha$ Cre driver mice (Tsien et al., 1996; Luikart et al., 2005; Monteggia et al., 2007; Wang et al., 2011a), we observed a large reduction in $\mathrm{Nampt}^{+}$cells, particularly in the hippocampal CA1 subregion, and a significant reduction in total hippocampal $\mathrm{NAD}^{+}$levels. Nonetheless, CaMKII $\alpha$ Nampt $t^{-1-}$ mice also displayed remarkable hippocampal changes without obvious apoptosis, necrosis, or autophagy. An intriguing change in CaMKII $\alpha N_{a m p t} t^{-1-}$ mice is their atrophied and swollen Map $2^{+}$dendrites, indicating altered neuronal connectivity. Supporting this notion, electrophysiological assessments revealed changes in the relationship between inputs and outputs in CA1. Namely, CaMKII $\alpha$ Nampt $t^{-1-}$ mice required larger presynaptic volleys to evoke maximal population spike firing. Presynaptic volleys represent the summed discharge of action potentials from afferent axons that arrive in CA1 after Schaffer collateral pathway stimulation. Therefore, larger presynaptic volleys suggest the need to recruit more presynaptic neurons and perhaps altered action potential initiation, propagation, and/or amplitude (Soleng et al., 2003; Meeks and Mennerick, 2004). In CaMKII $\alpha$ Nampt ${ }^{-1-}$ mice, Schaffer collateral pathway stimulation triggered synaptic responses (fEPSPs) that promoted spike firing. Moreover, CA1 glutamatergic synapses, once activated, could generate and sustain LTP. The normal fEPSPs observed in CaMKII $\alpha$ Nampt $t^{-1-}$ mice indicate that basal synaptic transmission, presynaptic neuron transmitter release, and postsynaptic neuronal responses are intact and not a primary defect, although more systematic evaluation could uncover changes in these parameters as well. Such defects in hippocampal function have not been observed in other models of disease (Schiff and
Somjen, 1985; Young and Somjen, 1992; Mitani et al., 1993), neurotransmitter imbalances (Konnerth and Heinemann, 1983), ionic imbalances (Balestrino et al., 1986), glycolytic blockade (Tekkök and Krnjević, 1995), or neuronal loss (Patterson et al., 1996). Importantly, excitotoxicity and glycolytic blockade increase presynaptic volley amplitude by increasing sodium entry and facilitating axonal excitability (Tekkök and Krnjević, 1996; Suárez et al., 2005; Winegar and MacIver, 2006). Therefore, it is possible that CaMKII $\alpha$ Nampt $t^{-1-}$ hippocampal neurons have an altered firing threshold.

With such profound histological and electrophysiological abnormalities, we predicted that CaMKII $\alpha$ Nampt $t^{-/-}$mice would show behavioral changes associated with altered CA1 function, including hyperactivity, reduced anxiety-like behaviors, and impaired cognition (Fanselow, 2000; Kubik et al., 2007; Barkus et al., 2010; Langston et al., 2010). Indeed, CaMKII $\alpha$ Nampt $t^{-/-}$ mice showed robust changes in all of the above. Most strikingly, CaMKII $\alpha$ Nampt $t^{-1-}$ mice required longer escape path lengths to find the platform in both the cued and place (spatial learning) conditions of the MWM. Although the performance of CaMKII $\alpha \mathrm{Nampt}^{-1-}$ mice was substantially inferior to control mice, they nevertheless showed improvement over time, suggesting some spatial learning. However, the lack of retention displayed by CaMKII $\alpha$ Nampt $t^{-/-}$mice during the probe trial implies that spatial learning and/or retention was minimal. This 
impairment in the MWM performance of CaMKII $\alpha$ Nampt $t^{-1-}$ mice is particularly surprising in light of their intact LTP. Indeed, previous work has strongly correlated MWM performance (Jeffery and Morris, 1993; Tombaugh et al., 2002) and expression of immediate early genes including Egrl (Davis et al., 2003) and Arc (Kubik et al., 2007) with LTP. Therefore, CaMKII $\alpha$ Nampt $t^{-1-}$ mice present an interesting discrepancy in functional, electrophysiological, and histopathological phenotypes.

Conditioned fear testing revealed that cognitive deficits in CaMKII $\alpha \mathrm{Nampt}^{-1-}$ mice extend to Pavlovian conditioning involving nonspatial learning and memory. During the T/S training, CaMKII $\alpha \mathrm{Nampt}^{-1-}$ mice showed much less freezing behavior than control mice, suggesting that the foot shocks produced less fear in these mice or that their hyperactivity made it difficult for them to remain motionless. CaMKII $\alpha$ Nampt ${ }^{-1-}$ mice displayed similar levels of freezing as control mice during the first 2 min of the contextual fear testing, but after these first 2 min, and during the auditory cue testing, CaMKII $\alpha$ Nampt ${ }^{-1-}$ mice showed little freezing behavior. Therefore, the T/S training may have produced some conditioned or generalized fear in CaMKII $\alpha \mathrm{Nampt}^{-1-}$ mice, the behavioral expression of which was compromised by hyperactivity. It will be interesting to evaluate aversive conditioning in $\mathrm{CaMKII} \alpha \mathrm{Nampt}^{-/-}$mice by procedures that do not use freezing as a primary outcome.

Our results suggest that CaMKII $\alpha \mathrm{Nampt}^{-1-}$ mice have cognitive deficits that are coupled with hyperactivity and abnormally low levels of anxiety-like behavior. Importantly, our findings that CaMKII $\alpha \mathrm{Nampt}^{-/-}$mice were more active than control mice in the threatening open arms of the EPM suggest that they may exhibit abnormal hyperactivity in environments that contain aversive stimuli. Additional studies are needed to determine whether the reduced anxiety-like behaviors in CaMKII $\alpha \mathrm{Nampt}^{-1-}$ mice represent altered emotionality or an inability to perceive danger. It is also interesting that CaMKII $\alpha \mathrm{Nampt}^{-1-}$ male mice showed more extensive body weight and activity phenotypes than CaMKII $\alpha \mathrm{Nampt}^{-/-}$female mice, considering that reducing Nampt activity in peripheral tissues generates stronger phenotypes in female mice than male mice (Revollo et al., 2007; Ramsey et al., 2008).

Although the hyperactivity, impaired learning and memory, and reduced levels of anxiety-like behaviors observed in CaMKII $\alpha$ Nampt $t^{-1-}$ mice correspond nicely with a loss of CA1 functionality, their impaired performance on the auditory cue testing does not (Fanselow, 2000; Kubik et al., 2007; Barkus et al., 2010; Langston et al., 2010). One explanation for this discrepancy is that the CA1 atrophy in CaMKII $\alpha \mathrm{Nampt}^{-1-}$ mice disrupted anatomical connections between CA1 and other brain areas, including the entorhinal cortex, DG, CA3, and subiculum areas, and thereby impaired their functions (Cantó et al., 2008; Langston et al., 2010; Piskorowski and Chevaleyre, 2012). Indeed, multiple regions of the cortex have been implicated in fear responses (Casey et al., 2013). It is also possible that the poor performance of CaMKII $\alpha$ Nampt $t^{-1-}$ mice on the auditory cue testing is the result of their hyperactivity. However, additional control groups (e.g., shock alone or "unpairing" of the tone and shock) are needed to determine whether auditory cue performance impairments result from "true conditioning" or other processes such as sensitization. Given the CA1 pathology in CaMKII $\alpha$ Nampt $t^{-1-}$ mice, we included the auditory cue testing as a control for the specificity of the contextual fear performance deficit.

Importantly, the collective cellular, physiological, and behavioral phenotypes displayed by CaMKII $\alpha \mathrm{Nampt}^{-1-}$ mice are specific to loss of Nampt-mediated $\mathrm{NAD}^{+}$biosynthesis.
CaMKII $\alpha$ Cre-driven deletion of multiple other factors produces forebrain degeneration, but with profoundly different chronologies, pathways of cell death, and behavioral effects from those we observed (Sörensen et al., 2001; Tabuchi et al., 2009; Hébert et al., 2010). Therefore, the phenotypes of CaMKII $\alpha \mathrm{Nampt}^{-/-}$mice cannot be equated with simple regional death and dysfunction. Instead, the complex array of phenotypes in CaMKII $\alpha \mathrm{Nampt}^{-1-}$ mice, in the absence of major health or sensory impairments, potentially place CaMKII $\alpha$ Nampt $t^{-1-}$ mice as a novel model of CA1 dysfunction. Such a model has considerable value because CA1 sustains more damage than other hippocampal subregions in many prevalent diseases and conditions, including ischemia (Calabresi et al., 2003; Crepel et al., 2003; Nikonenko et al., 2009), excitotoxicity (Stanika et al., 2010), status epilepticus (do Nascimento et al., 2012), and Alzheimer's disease (Apostolova et al., 2010; Costafreda et al., 2011; Padurariu et al., 2012).

Currently, the mechanism(s) downstream of Nampt is unknown. Although $\mathrm{NAD}^{+}$is best known for redox recycling, it also functions as a substrate for several families of enzymes, including sirtuins (e.g., Sirt1), PARPs (e.g., Parp1), and CD38/157 cADP-ribose synthases (Houtkooper et al., 2010; Stein and Imai, 2012). However, the CaMKII $\alpha \mathrm{Nampt}^{-/-}$phenotypes do not appear to result from loss of Sirt1 or Parp1 function. CaMKII $\alpha$ driven loss of Sirt1 does not generate overt CA1 and cortical atrophy (data not shown). Moreover, both deletion of Sirt1 (Gao et al., 2010; Michán et al., 2010) and inhibition of Parp1 (FontánLozano et al., 2010) impair LTP. Furthermore, neither Sirt1 (Gao et al., 2010; Michán et al., 2010; Wu et al., 2011; Gräff et al., 2013) nor Parp1 (Fontán-Lozano et al., 2010) conclusively affect activity. Conversely, it is plausible that loss of CD38/157 activity contributes to CaMKII $\alpha$ Nampt ${ }^{-1-}$ phenotypes because CD38/157 generates the second messenger cADP-ribose, which contributes to calcium mobilization via ryanodine receptors (Sauve, 2008; Young and Kirkland, 2008; Houtkooper et al., 2010).

There is clearly an impetus to investigate novel molecules involved in CA1 function. Cerebral ischemia, childhood-onset psychiatric disorders, and dementia are major causes of death and disability (Nikonenko et al., 2009; Frisardi et al., 2010; Robertson and Feng, 2011; Sartori et al., 2011; Kvajo et al., 2012). Establishing animal models is essential for understanding the pathology of these diseases, yet this is difficult because of their multifaceted environmental and genetic causes (Kvajo et al., 2012). To our knowledge, this is the first study to show that forebrain excitatory neuron ablation of Nampt has serious repercussions for neuronal function and survival, which affects associated cognitive capabilities and behaviors. Further investigation of CaMKII $\alpha \mathrm{Nampt}^{-1-}$ mice should provide valuable information regarding CA1 and cortical neuron vulnerability, function, and properties.

\section{References}

Aarts MM, Tymianski M (2004) Molecular mechanisms underlying specificity of excitotoxic signaling in neurons. Curr Mol Med 4:137-147. CrossRef Medline

Apostolova LG, Mosconi L, Thompson PM, Green AE, Hwang KS, Ramirez A, Mistur R, Tsui WH, de Leon MJ (2010) Subregional hippocampal atrophy predicts Alzheimer's dementia in the cognitively normal. Neurobiol Aging 31:1077-1088. CrossRef Medline

Balestrino M, Aitken PG, Somjen GG (1986) The effects of moderate changes of extracellular $\mathrm{K}+$ and $\mathrm{Ca} 2+$ on synaptic and neural function in the CA1 region of the hippocampal slice. Brain Res 377:229-239. CrossRef Medline

Barkus C, McHugh SB, Sprengel R, Seeburg PH, Rawlins JN, Bannerman DM (2010) Hippocampal NMDA receptors and anxiety: at the interface between cognition and emotion. Eur J Pharmacol 626:49-56. CrossRef Medline 
Barros LF, Deitmer JW (2010) Glucose and lactate supply to the synapse. Brain Res Rev 63:149-159. CrossRef Medline

Bevers MB, Neumar RW (2008) Mechanistic role of calpains in postischemic neurodegeneration. J Cereb Blood Flow Metab 28:655-673. CrossRef Medline

Bukalo O, Dityatev A (2006) Analysis of neural cell functions in gene knockout mice: electrophysiological investigation of synaptic plasticity in acute hippocampal slices. Meth Enzymol 417:52-66. CrossRef Medline

Calabresi P, Centonze D, Pisani A, Cupini L, Bernardi G (2003) Synaptic plasticity in the ischaemic brain. Lancet Neurol 2:622-629. CrossRef Medline

Cantó CB, Wouterlood FG, Witter MP (2008) What does the anatomical organization of the entorhinal cortex tell us? Neural Plast 2008:381243. CrossRef Medline

Capogna M (1998) Presynaptic facilitation of synaptic transmission in the hippocampus. Pharmacol Ther 77:203-223. CrossRef Medline

Casey BJ, Pattwell SS, Glatt CE, Lee FS (2013) Treating the developing brain: implications from human imaging and mouse genetics. Annu Rev Med 64:427-439. CrossRef Medline

Costafreda SG, Dinov ID, Tu Z, Shi Y, Liu CY, Kloszewska I, Mecocci P, Soininen H, Tsolaki M, Vellas B, Wahlund LO, Spenger C, Toga AW, Lovestone S, Simmons A (2011) Automated hippocampal shape analysis predicts the onset of dementia in mild cognitive impairment. Neuroimage 56:212-219. CrossRef Medline

Crepel V, Epsztein J, Ben-Ari Y (2003) Ischemia induces short- and longterm remodeling of synaptic activity in the hippocampus. J Cell Mol Med 7:401-407. CrossRef Medline

Davis S, Bozon B, Laroche S (2003) How necessary is the activation of the immediate early gene zif268 in synaptic plasticity and learning? Behav Brain Res 142:17-30. CrossRef Medline

do Nascimento AL, Dos Santos NF, Campos Pelágio F, Aparecida Teixeira S, de Moraes Ferrari EA, Langone F (2012) Neuronal degeneration and gliosis time-course in the mouse hippocampal formation after pilocarpine-induced status epilepticus. Brain Res 1470:98-110. CrossRef Medline

Dougherty JD, Maloney SE, Wozniak DF, Rieger MA, Sonnenblick L, Coppola G, Mahieu NG, Zhang J, Cai J, Patti GJ, Abrahams BS, Geschwind DH, Heintz N (2013) The disruption of Celf6, a gene identified by translational profiling of serotonergic neurons, results in autism-related behaviors. J Neurosci 33:2732-2753. CrossRef Medline

Fanselow MS (2000) Contextual fear, gestalt memories, and the hippocampus. Behav Brain Res 110:73-81. CrossRef Medline

Folkerts MM, Berman RF, Muizelaar JP, Rafols JA (1998) Disruption of MAP-2 immunostaining in rat hippocampus after traumatic brain injury. J Neurotrauma 15:349-363. CrossRef Medline

Fontán-Lozano A, Suárez-Pereira I, Horrillo A, del-Pozo-Martín Y, Hmadcha A, Carrión AM (2010) Histone H1 poly[ADP]-ribosylation regulates the chromatin alterations required for learning consolidation. J Neurosci 30:13305-13313. CrossRef Medline

Friebe D, Neef M, Kratzsch J, Erbs S, Dittrich K, Garten A, Petzold-Quinque S, Blüher S, Reinehr T, Stumvoll M, Blüher M, Kiess W, Körner A (2011) Leucocytes are a major source of circulating nicotinamide phosphoribosyltransferase (NAMPT)/pre-B cell colony (PBEF)/visfatin linking obesity and inflammation in humans. Diabetologia 54:1200-1211. CrossRef Medline

Frisardi V, Solfrizzi V, Seripa D, Capurso C, Santamato A, Sancarlo D, Vendemiale G, Pilotto A, Panza F (2010) Metabolic-cognitive syndrome: a cross-talk between metabolic syndrome and Alzheimer's disease. Ageing Res Rev 9:399-417. CrossRef Medline

Gao J, Wang WY, Mao YW, Gräff J, Guan JS, Pan L, Mak G, Kim D, Su SC, Tsai LH (2010) A novel pathway regulates memory and plasticity via SIRT1 and miR-134. Nature 466:1105-1109. CrossRef Medline

Grady RM, Wozniak DF, Ohlemiller KK, Sanes JR (2006) Cerebellar synaptic defects and abnormal motor behavior in mice lacking alpha- and betadystrobrevin. J Neurosci 26:2841-2851. CrossRef Medline

Gräff J, Kahn M, Samiei A, Gao J, Ota KT, Rei D, Tsai LH (2013) A dietary regimen of caloric restriction or pharmacological activation of SIRT1 to delay the onset of neurodegeneration. J Neurosci 33:8951-8960. CrossRef Medline

Hébert SS, Papadopoulou AS, Smith P, Galas MC, Planel E, Silahtaroglu AN, Sergeant N, Bueé L, De Strooper B (2010) Genetic ablation of Dicer in adult forebrain neurons results in abnormal tau hyperphosphorylation and neurodegeneration. Hum Mol Genet 19:3959-3969. CrossRef Medline

Hirrlinger J, Dringen R (2010) The cytosolic redox state of astrocytes: Main- tenance, regulation and functional implications for metabolite trafficking. Brain Res Rev 63:177-188. CrossRef Medline

Houtkooper RH, Cantó C, Wanders RJ, Auwerx J (2010) The secret life of $\mathrm{NAD}+$ : an old metabolite controlling new metabolic signaling pathways. Endocr Rev 31:194-223. CrossRef Medline

Izumi Y, Katsuki H, Zorumski CF (1997) Monocarboxylates (pyruvate and lactate) as alternative energy substrates for the induction of long-term potentiation in rat hippocampal slices. Neurosci Lett 232:17-20. CrossRef Medline

Jalava NS, Lopez-Picon FR, Kukko-Lukjanov TK, Holopainen IE (2007) Changes in microtubule-associated protein-2 (MAP2) expression during development and after status epilepticus in the immature rat hippocampus. Int J Dev Neurosci 25:121-131. CrossRef Medline

Jeffery KJ, Morris RG (1993) Cumulative long-term potentiation in the rat dentate gyrus correlates with, but does not modify, performance in the water maze. Hippocampus 3:133-140. CrossRef Medline

Khuchua Z, Wozniak DF, Bardgett ME, Yue Z, McDonald M, Boero J, Hartman RE, Sims H, Strauss AW (2003) Deletion of the N-terminus of murine map 2 by gene targeting disrupts hippocampal cal neuron architecture and alters contextual memory. Neuroscience 119:101-111. CrossRef Medline

Kitagawa K, Matsumoto M, Niinobe M, Mikoshiba K, Hata R, Ueda H, Handa N, Fukunaga R, Isaka Y, Kimura K, et al. (1989) Microtubuleassociated protein 2 as a sensitive marker for cerebral ischemic damageimmunohistochemical investigation of dendritic damage. Neuroscience 31:401-411. CrossRef Medline

Kitani T, Okuno S, Fujisawa H (2003) Growth phase-dependent changes in the subcellular localization of pre-B-cell colony-enhancing factor. FEBS Lett 544:74-78. CrossRef Medline

Konnerth A, Heinemann U (1983) Effects of GABA on presumed presynaptic Ca2 + entry in hippocampal slices. Brain Res 270:185-189. CrossRef Medline

Kubik S, Miyashita T, Guzowski JF (2007) Using immediate-early genes to map hippocampal subregional functions. Learn Mem 14:758-770. CrossRef Medline

Kvajo M, McKellar H, Gogos JA (2012) Avoiding mouse traps in schizophrenia genetics: lessons and promises from current and emerging mouse models. Neuroscience 211:136-164. CrossRef Medline

Kwei S, Jiang C, Haddad GG (1993) Acute anoxia-induced alterations in MAP2 immunoreactivity and neuronal morphology in rat hippocampus. Brain Res 620:203-210. CrossRef Medline

Langston RF, Stevenson CH, Wilson CL, Saunders I, Wood ER (2010) The role of hippocampal subregions in memory for stimulus associations. Behav Brain Res 215:275-291. CrossRef Medline

Luikart BW, NefS, Virmani T, Lush ME, Liu Y, KavalaliET, Parada LF (2005) TrkB has a cell-autonomous role in the establishment of hippocampal Schaffer collateral synapses. J Neurosci 25:3774-3786. CrossRef Medline

Lunt SY, Vander Heiden MG (2011) Aerobic glycolysis: meeting the metabolic requirements of cell proliferation. Annu Rev Cell Dev Biol 27:441464. CrossRef Medline

Matesic DF, Lin RC (1994) Microtubule-associated protein 2 as an early indicator of ischemia-induced neurodegeneration in the gerbil forebrain. J Neurochem 63:1012-1020. CrossRef Medline

Meeks JP, Mennerick S (2004) Selective effects of potassium elevations on glutamate signaling and action potential conduction in hippocampus. J Neurosci 24:197-206. CrossRef Medline

Michán S, Li Y, Chou MM, Parrella E, Ge H, Long JM, Allard JS, Lewis K, Miller M, Xu W, Mervis RF, Chen J, Guerin KI, Smith LE, McBurney MW, Sinclair DA, Baudry M, de Cabo R, Longo VD (2010) SIRT1 is essential for normal cognitive function and synaptic plasticity. J Neurosci 30:9695-9707. CrossRef Medline

Minger SL, Geddes JW, Holtz ML, Craddock SD, Whiteheart SW, Siman RG, Pettigrew LC (1998) Glutamate receptor antagonists inhibit calpainmediated cytoskeletal proteolysis in focal cerebral ischemia. Brain Res 810:181-199. CrossRef Medline

Mitani A, Yanase H, Sakai K, Wake Y, Kataoka K (1993) Origin of intracellular $\mathrm{Ca} 2+$ elevation induced by in vitro ischemia-like condition in hippocampal slices. Brain Res 601:103-110. CrossRef Medline

Monteggia LM, Luikart B, Barrot M, Theobold D, Malkovska I, Nef S, Parada LF, Nestler EJ (2007) Brain-derived neurotrophic factor conditional knockouts show gender differences in depression-related behaviors. Biol Psychiatry 61:187-197. CrossRef Medline

Nicoll RA, Malenka RC (1999) Expression mechanisms underlying NMDA 
receptor-dependent long-term potentiation. Ann N Y Acad Sci 868:515525. CrossRef Medline

Nikonenko AG, Radenovic L, Andjus PR, Skibo GG (2009) Structural features of ischemic damage in the hippocampus. Anat Rec (Hoboken) 292: 1914-1921. CrossRef Medline

Padurariu M, Ciobica A, Mavroudis I, Fotiou D, Baloyannis S (2012) Hippocampal neuronal loss in the CA1 and CA3 areas of Alzheimer's disease patients. Psychiatria Danubina 24:152-158. Medline

Patterson SL, Abel T, Deuel TA, Martin KC, Rose JC, Kandel ER (1996) Recombinant BDNF rescues deficits in basal synaptic transmission and hippocampal LTP in BDNF knockout mice. Neuron 16:1137-1145. CrossRef Medline

Pellerin L, Bouzier-Sore AK, Aubert A, Serres S, Merle M, Costalat R, Magistretti PJ (2007) Activity-dependent regulation of energy metabolism by astrocytes: an update. Glia 55:1251-1262. CrossRef Medline

Pettigrew LC, Holtz ML, Craddock SD, Minger SL, Hall N, Geddes JW (1996) Microtubular proteolysis in focal cerebral ischemia. J Cereb Blood Flow Metab 16:1189-1202. CrossRef Medline

Piskorowski RA, Chevaleyre V (2012) Synaptic integration by different dendritic compartments of hippocampal CA1 and CA2 pyramidal neurons. Cell Mol Life Sci 69:75-88. CrossRef Medline

Pittelli M, Formentini L, Faraco G, Lapucci A, Rapizzi E, Cialdai F, Romano G, Moneti G, Moroni F, Chiarugi A (2010) Inhibition of nicotinamide phosphoribosyltransferase: cellular bioenergetics reveals a mitochondrial insensitive NAD pool. J Biol Chem 285:34106-34114. CrossRef Medline

Ramsey KM, Mills KF, Satoh A, Imai S (2008) Age-associated loss of Sirt1mediated enhancement of glucose-stimulated insulin secretion in beta cell-specific Sirt1-overexpressing (BESTO) mice. Aging Cell 7:78-88. CrossRef Medline

Revollo JR, Grimm AA, Imai S (2004) The NAD biosynthesis pathway mediated by nicotinamide phosphoribosyltransferase regulates Sir2 activity in mammalian cells. J Biol Chem 279:50754-50763. CrossRef Medline

Revollo JR, Körner A, Mills KF, Satoh A, Wang T, Garten A, Dasgupta B, Sasaki Y, Wolberger C, Townsend RR, Milbrandt J, Kiess W, Imai S (2007) Nampt/ $\mathrm{PBEF} /$ Visfatin regulates insulin secretion in beta cells as a systemic NAD biosynthetic enzyme. Cell Metab 6:363-375. CrossRef Medline

Robertson HR, Feng G (2011) Annual Research Review: Transgenic mouse models of childhood-onset psychiatric disorders. Journal of child psychology and psychiatry, and allied disciplines 52:442-475. CrossRef Medline

Rongvaux A, Galli M, Denanglaire S, Van Gool F, Drèze PL, Szpirer C, Bureau F, Andris F, Leo O (2008) Nicotinamide phosphoribosyl transferase/ pre-B cell colony-enhancing factor/visfatin is required for lymphocyte development and cellular resistance to genotoxic stress. J Immunol 181: 4685-4695. Medline

Santos MS, Li H, Voglmaier SM (2009) Synaptic vesicle protein trafficking at the glutamate synapse. Neuroscience 158:189-203. CrossRef Medline

Sartori SB, Landgraf R, Singewald N (2011) The clinical implications of mouse models of enhanced anxiety. Future Neurol 6:531-571. CrossRef Medline

Sasaki Y, Araki T, Milbrandt J (2006) Stimulation of nicotinamide adenine dinucleotide biosynthetic pathways delays axonal degeneration after axotomy. J Neurosci 26:8484-8491. CrossRef Medline

Sato C, Turkoz M, Dearborn JT, Wozniak DF, Kopan R, Hass MR (2012) Loss of RBPj in postnatal excitatory neurons does not cause neurodegeneration or memory impairments in aged mice. PLoS One 7:e48180. CrossRef Medline

Sauve AA (2008) NAD+ and vitamin B3: from metabolism to therapies. J Pharmacol Exp Ther 324:883-893. CrossRef Medline

Schaefer ML, Wong ST, Wozniak DF, Muglia LM, Liauw JA, Zhuo M, Nardi A, Hartman RE, Vogt SK, Luedke CE, Storm DR, Muglia LJ (2000) Altered stress-induced anxiety in adenylyl cyclase type VIII-deficient mice. J Neurosci 20:4809-4820. Medline

Schiff SJ, Somjen GG (1985) Hyperexcitability following moderate hypoxia in hippocampal tissue slices. Brain Res 337:337-340. CrossRef Medline

Soleng AF, Chiu K, Raastad M (2003) Unmyelinated axons in the rat hippocampus hyperpolarize and activate an $\mathrm{H}$ current when spike frequency exceeds $1 \mathrm{~Hz}$. J Physiol 552:459-470. CrossRef Medline

Sörensen L, Ekstrand M, Silva JP, Lindqvist E, Xu B, Rustin P, Olson L, Larsson NG (2001) Late-onset corticohippocampal neurodepletion attributable to catastrophic failure of oxidative phosphorylation in MILON mice. J Neurosci 21:8082-8090. Medline

Stanika RI, Winters CA, Pivovarova NB, Andrews SB (2010) Differential NMDA receptor-dependent calcium loading and mitochondrial dysfunc- tion in CA1 vs. CA3 hippocampal neurons. Neurobiol Dis 37:403-411. CrossRef Medline

Stein LR, Imai S (2012) The dynamic regulation of NAD metabolism in mitochondria. Trends Endocrinol Metab 23:420-428. CrossRef Medline

Suárez LM, Suárez F, Del Olmo N, Ruiz M, González-Escalada JR, Solís JM (2005) Presynaptic NMDA autoreceptors facilitate axon excitability: a new molecular target for the anticonvulsant gabapentin. Eur J Neurosci 21:197-209. CrossRef Medline

Tabuchi K, Chen G, Südhof TC, Shen J (2009) Conditional forebrain inactivation of nicastrin causes progressive memory impairment and agerelated neurodegeneration. J Neurosci 29:7290-7301. CrossRef Medline

Tekkök S, Krnjević K (1995) Long-term potentiation in hippocampal slices induced by temporary suppression of glycolysis. J Neurophysiol 74:27632766. Medline

Tekkök S, Krnjević K (1996) Calcium dependence of LTP induced by 2-deoxyglucose in CA1 neurons. J Neurophysiol 76:2343-2352. Medline

Tokuda K, O'Dell KA, Izumi Y, Zorumski CF (2010) Midazolam inhibits hippocampal long-term potentiation and learning through dual central and peripheral benzodiazepine receptor activation and neurosteroidogenesis. J Neurosci 30:16788-16795. CrossRef Medline

Tombaugh GC, Rowe WB, Chow AR, Michael TH, Rose GM (2002) Thetafrequency synaptic potentiation in CA1 in vitro distinguishes cognitively impaired from unimpaired aged Fischer 344 rats. J Neurosci 22:99329940. Medline

Tsien JZ, Chen DF, Gerber D, Tom C, Mercer EH, Anderson DJ, Mayford M, Kandel ER, Tonegawa S (1996) Subregion- and cell type-restricted gene knockout in mouse brain. Cell 87:1317-1326. CrossRef Medline

Verderio C, Bruzzone S, Zocchi E, Fedele E, Schenk U, De Flora A, Matteoli M (2001) Evidence of a role for cyclic ADP-ribose in calcium signalling and neurotransmitter release in cultured astrocytes. J Neurochem 78:646657. CrossRef Medline

Wang L, Budolfson K, Wang F (2011a) Pik3c3 deletion in pyramidal neurons results in loss of synapses, extensive gliosis and progressive neurodegeneration. Neuroscience 172:427-442. CrossRef Medline

Wang P, Xu TY, Guan YF, Tian WW, Viollet B, Rui YC, Zhai QW, Su DF, Miao CY (2011b) Nicotinamide phosphoribosyltransferase protects against ischemic stroke through SIRT1-dependent adenosine monophosphate-activated kinase pathway. Ann Neurol 69:360-374. CrossRef Medline

Wilson NR, Kang J, Hueske EV, Leung T, Varoqui H, Murnick JG, Erickson JD, Liu G (2005) Presynaptic regulation of quantal size by the vesicular glutamate transporter VGLUT1. J Neurosci 25:6221-6234. CrossRef Medline

Winegar BD, MacIver MB (2006) Isoflurane depresses hippocampal CA1 glutamate nerve terminals without inhibiting fiber volleys. BMC Neurosci 7:5. CrossRef Medline

Wojcik SM, Rhee JS, Herzog E, Sigler A, Jahn R, Takamori S, Brose N, Rosenmund C (2004) An essential role for vesicular glutamate transporter 1 (VGLUT1) in postnatal development and control of quantal size. Proc Natl Acad Sci U S A 101:7158-7163. CrossRef Medline

Wozniak DF, Hartman RE, Boyle MP, Vogt SK, Brooks AR, Tenkova T, Young C, Olney JW, Muglia LJ (2004) Apoptotic neurodegeneration induced by ethanol in neonatal mice is associated with profound learning/ memory deficits in juveniles followed by progressive functional recovery in adults. Neurobiol Dis 17:403-414. CrossRef Medline

Wozniak DF, Xiao M, Xu L, Yamada KA, Ornitz DM (2007) Impaired spatial learning and defective theta burst induced LTP in mice lacking fibroblast growth factor 14. Neurobiol Dis 26:14-26. CrossRef Medline

Wu D, Qiu Y, Gao X, Yuan XB, Zhai Q (2011) Overexpression of SIRT1 in mouse forebrain impairs lipid/glucose metabolism and motor function. PLoS One 6:e21759. CrossRef Medline

Yoshino J, Mills KF, Yoon MJ, Imai S (2011) Nicotinamide mononucleotide, a key $\mathrm{NAD}(+)$ intermediate, treats the pathophysiology of diet- and ageinduced diabetes in mice. Cell Metab 14:528-536. CrossRef Medline

Young GS, Kirkland JB (2008) The role of dietary niacin intake and the adenosine-5' -diphosphate-ribosyl cyclase enzyme CD38 in spatial learning ability: is cyclic adenosine diphosphate ribose the link between diet and behaviour? Nutr Res Rev 21:42-55. CrossRef Medline

Young JN, Somjen GG (1992) Suppression of presynaptic calcium currents by hypoxia in hippocampal tissue slices. Brain Res 573:70-76. CrossRef Medline

Zhang W, Xie Y, Wang T, Bi J, Li H, Zhang LQ, Ye SQ, Ding S (2010) Neuronal protective role of $\mathrm{PBEF}$ in a mouse model of cerebral ischemia. J Cereb Blood Flow Metab 30:1962-1971. CrossRef Medline 